\title{
The neglected complexities of shark fisheries, and priorities for
}

\section{holistic risk-based management}

1

\section{Abstract}

Sharks and their cartilaginous relatives (Class Chondricthyes, herein 'sharks') are one of the world's most threatened species groups. Their slow life history traits and vulnerability to capture make them particularly susceptible to overfishing, and they are widely caught in both target and bycatch fisheries, with global demand for shark products maintaining an economically profitable industry for exploitation. This is exacerbated by a lack of science-based management, with regulatory action further complicated by the socio-economic vulnerability of small-scale tropical fisheries, which are responsible for large proportions of shark catch. To date, much shark research has focused on lifehistory (biological) and fisheries' operational (technical) factors that influence overfishing, and on developing associated technical measures and direct regulation to address these factors. However, shark mortality reduction is more than a biological and technical issue - it entails changing fisher behaviour in the context of an economically valuable industry, and socially vulnerable coastal communities. Acknowledging this, we review typical measures for understanding and managing risks to sharks, and discuss the neglected socio-economic complexities of managing shark mortality. We explore why technical measures alone may fail, and therefore why a holistic approach to riskbased shark management is required, which explicitly considers socio-economic determinants of feasibility, alongside biological and technical risk, in management decision-making. Based on this, we propose the first framework for assessing feasibility in a shark management context, and discuss priorities for research and implementation. Overall, this will facilitate the design of nuanced management measures, with mixes of policies and instruments that are tailored to the characteristics of specific species, fisheries and contexts. This holistic approach is essential for feasible, effective and ethical shark management, which improves outcomes for sharks and people.

Key words: elasmobranchs; regulation; incentives; social norms; socio-economics; small-scale fisheries; fishers; feasibility; conservation planning 


\section{Background}

Sharks and their cartilaginous relatives (Class Chondrichthyes, herein 'sharks') are one of the world's most threatened species groups (Dulvy et al., 2014). This is primarily due to overfishing - with high levels of fishing mortality (Worm et al., 2013), and conservative life-history traits that make many shark species intrinsically vulnerable to overexploitation (Stevens, Bonfil, Dulvy, \& Walker, 2000; Ward-Paige, Keith, \& Lotze, 2012). This fishing pressure is driven in part by growing international demand for shark-derived commodities (most notably fins, but also meat, cartilage, liver oil), which creates a high market value for sharks; as well as a general expansion of global fisheries, with high levels of by-catch (Clarke et al., 2006; Dent \& Clarke, 2014; Oliver, Braccini, Newman, \& Harvey, 2015) and limited incentives to reduce retention (James, Lewison, Dillingham, \& Moore, 2016). It is estimated that at least 100 million sharks are killed annually, exceeding the average rebound potential of most sharks (Worm et al., 2013). With rapid declines documented for many shark populations (Baum et al., 2003; Dulvy et al., 2008; Ferretti, Worm, Britten, Heithaus, \& Lotze, 2010; Musick, Burgess, Cailliet, Camhi, \& Fordham, 2000), a quarter of shark species are now estimated to be threatened with extinction (Dulvy et al., 2014).

The disappearance of sharks from our waters is troubling for several reasons. Sharks comprise one of the world's most ancient, widespread and diverse clades of predators (White \& Last, 2012), representing thousands of years of unique evolutionary history (Stein et al., 2018). They serve a wide variety of ecosystem functions and play critical roles in integrating trophic cascades and maintaining functional and productive ocean ecosystems (Stevens et al., 2000; Myers et al., 2007; Ferretti et al., 2010; Heupel et al. 2014; Grubbs et al., 2016; Dulvy et al., 2017). As a marine resource, sharks contribute at least US $\$ 1$ billion to national economies annually through fisheries, trade and tourism value (Cisneros-Montemayor, Barnes-Mauthe, Al-Abdulrazzak, Navarro-Holm, \& Sumaila, 2013; Dent \& Clarke, 2014; O’Malley, Lee-Brooks, \& Medd, 2013), and are intrinsically linked to the livelihoods, well-being and cultural identity of many coastal communities (e.g. Leeney and Poncelet, 2015; Lestari et al., 2017; Glaus et al., 2018; Leeney, Mana and Dulvy, 2018). Yet despite their ecological and socioeconomic importance, the value of sharks isn't reflected in their management (Lack 
\& Sant, 2011). Unlike other commercially important fish species, such as tuna, or charismatic marine megafauna with similar life histories and ecotourism potential, such as cetaceans, sharks are exceptionally under-managed (Dulvy et al., 2017). Limited political will and insufficient economic incentives for better management, coupled with poor data and policy complexity, has maintained a state of inaction for effective shark management (Barker \& Schluessel, 2005; Dulvy et al., 2017; Lack \& Sant, 2011).

Since 2013, the Convention on International Trade in Endangered Species of Wild Fauna and Flora (CITES) has played a major role in driving top-down regulatory change, through listings of several commercially important species on Appendix II, requiring that trade in these species is sustainable. Some shark species are also regulated under the Convention on Migratory Species (CMS) and various Regional Fisheries Management Organisations (RFMOs). Yet in order to deliver meaningful conservation outcomes, these efforts must translate in to fisheries management action at national and local levels. Specifically, management actions are required that lead to major reductions in shark fishing mortality, particularly for the most threatened and vulnerable species, and in the largest producing countries. However, robust shark fisheries management remains the preserve of a few market-oriented hyper-developed nations (e.g. Australia, New Zealand, USA), while fisheries in lowerincome countries, which constitute the majority of global shark production, remain under-managed (Momigliano \& Harcourt, 2014; Simpfendorfer \& Dulvy, 2017), and sharks continue to be overfished in most of the world (Davidson, Krawchuk, \& Dulvy, 2016).

Management in lower income countries is hampered by limited resources and capacity (Dharmadi, Fahmi, \& Satria, 2015; Momigliano \& Harcourt, 2014). Regulatory action is further complicated by the prevalence of small-scale mixed-species fisheries, which are ubiquitous throughout the coastal waters of fishery-dependent developing nations. Small-scale fisheries can be responsible for significant proportions of shark fishing mortality, yet they are often informal, unmonitored and unmanaged, with socially-oriented governance, while the coastal communities depending on them are often poor and socio-economically vulnerable (Glaus et al., 2018; Jaiteh, Loneragan, \& Warren, 2017; Lestari et al., 2017; Yulianto et al., 2018). What is more, reducing shark fishing mortality ultimately requires 
changing human behaviour, in particular, influencing the decisions of fishers and skippers at the point of catch. As such, there is a need for a social sciences perspective on shark fisheries, which can facilitate the design of local-level, bottom-up approaches, to complement macro-scale policy interventions and ensure implementation. Despite this, socio-economic factors are rarely incorporated in to shark research, and are not typically considered in shark risk assessments or management decisions, with significant research gaps on the human dimensions of shark conservation and calls for greater inclusion of local people in shark management planning (MacKeracher, Diedrich, \& Simpfendorfer, 2018; Rigby et al., 2019; Simpfendorfer, Heupel, White, \& Dulvy, 2011).

Acknowledging this gap, this article first reviews and categorises current approaches for conceptualising and managing risks to sharks in fisheries. We take a risk-based approach, since risk assessments are commonly used to understand and manage the impacts of economic development activities on natural resources (e.g. through Environmental and Social Risk Assessments (ESRA), and quantify extinction probabilities and threats to sharks in marine fisheries (Cortés et al., 2010; Dulvy et al., 2014). Risk assessments also provide a practical, data-driven means for prioritising management action, which can be used flexibly in data poor contexts, as is needed for sharks (Arrizabalaga et al., 2011; Braccini, Gillanders, \& Walker, 2006; Cortés et al., 2010). Through this review, we demonstrate that current approaches focus on biological, technical or macro-economic risks to sharks, while neglecting local-level socio-economic factors which drive fishing behaviour. We propose that this focus is based on three implicit but flawed assumptions about the nature of shark fishing and trade. We go on to explore why these assumptions are flawed, based on practical examples from shark conservation and broader marine management literature, and why typical approaches may therefore fail in practice. We demonstrate that there is a socio-economic implementation gap in current shark research and practice, which needs to be addressed. Finally, we propose some priorities for holistic risk-based shark management that can help to bridge this gap. In particular, we argue that the integration of feasibility assessments with traditional fisheries risk assessments could support improved planning, policy-making, and ultimately better outcomes for sharks and people. 


\section{Typical measures for managing shark mortality}

\subsection{Biological and technical risk}

Over the past decade, much applied research for shark management has focused on understanding the biological (i.e. intrinsic physiological and life history characteristics of sharks) and technical (i.e. fisheries operations and technology) factors that influence overfishing and extinction risk in sharks. There is now a considerable body of evidence describing these factors, and their role in risks to sharks. Biological factors include the influence of size, fecundity, habitat preference, depth range, and geographic range of on risk of capture and overexploitation (Dulvy et al., 2014); and the influence of morphology, locomotor performance, and respiratory and metabolic physiology on post-capture mortality (Braccini, Van Rijn, \& Frick, 2012; Gallagher, Orbesen, Hammerschlag, \& Serafy, 2014; Manire, Hueter, Hull, \& Spieler, 2001). Technical factors include those relating to the fishing process and technology, such as gear type and associated modifications (such as use of bycatch reduction technologies (BRT)), set depth, soak time, fishing ground, fishing time, fishing season, target species, and post-capture handling practices (Dapp, Huveneers, Walker, Drew, \& Reina, 2016; Gallagher et al., 2014; James et al., 2016; Oliver et al., 2015; Patterson, Hansen, \& Larcombe, 2014; Poisson, Gaertner, Taquet, Durbec, \& Bigelow, 2010; Thorpe \& Frierson, 2009; Ward, Lawrence, Darbyshire, \& Hindmarsh, 2008) (Table 1).

These factors represent varying degrees of risk to different shark species in different fisheries contexts, and are increasingly used to systematically estimate risks to sharks in marine fisheries using an ecological risk assessment (ERA) approach. A common, semi-quantitative ERA method, which has proven particularly useful for data-poor contexts and understanding shark vulnerability, is Productivity-Susceptibility Analysis (PSA) (Cortés et al., 2010; Gallagher, Kyne, \& Hammerschlag, 2012; Hobday et al., 2007). The PSA technique quantifies the relative vulnerability of shark species to a fishery by combining productivity (i.e. biological) and susceptibility (i.e. technical) variables to give an overall score (Arrizabalaga et al., 2011; Cortés et al., 2010). 
Understanding these biological and technical risk factors is important, because they allow scientists and managers to assess the vulnerability of different species within a comparative framework, for use in conservation prioritisation and management strategy design (e.g. Dulvy et al., 2014). This then helps in the design of technical measures to reduce the risk of fishing mortality for sharks (Table 1). For example, use of nylon leaders and circle hooks can reduce shark mortality in pelagic longline fisheries (Cooke \& Suski, 2004; Ward et al., 2008); modifying mesh sizes and net tension can minimize of susceptibility of certain species and life history stages to meshing and entanglement gillnets (Harry et al., 2011; Thorpe \& Frierson, 2009); attractants, deterrents or backdown procedures can reduce capture of pelagic sharks in purse seine vessels fishing on fish aggregation devices (FADs); and the use of exclusion or escape devices are effective for reducing capture of large sharks and rays from trawls (Brewer et al., 2006). However, many of these technical measures, while scientifically tested, are yet to be fully incorporated into fisheries policy and practice.

\subsection{Macro-economic risk}

At the other end of the supply chain, it is widely acknowledged that international demand for sharkderived consumer products, in particular fins for shark fin soup, creates a significant macroeconomic driving force for shark mortality (Clarke, Milner-Gulland, \& Bjørndal, 2007). This high value market is a driver for targeted shark fishing, finning, and the retention of incidentally caught sharks as marketable secondary catch (Clarke et al., 2007; Davidson et al., 2016). Davidson et al. (2016) also found that the scale of the meat trade influences shark overfishing, while McClenachan and colleagues found that economic value is the key factor explaining extinction risk for large-bodied shark species once they reach a certain threshold value (McClenachan, Cooper, \& Dulvy, 2016). Species above this threshold include whale sharks (Rhincodon typus), hammerhead sharks (Sphyrna spp.) and sawfish (Pristidae spp.) (McClenachan, Cooper, \& Dulvy, 2016). Anthropogenic factors, such as population size and accessibility, and governance factors, such as regulation and marine protected area networks, also play a role in moderating these macroeconomic impacts (Cinner et al., 2018; Davidson et al., 2016). 
Understanding these factors is important, because they can inform high-level international policy and trade-based interventions, such as those under CITES, as well as direct interventions in trading and consumer countries to reduce demand and market value. Typical macro-economic measures implemented to date include fin bans, species-specific trade bans, or countries banning all commercial fishing and trade of sharks and shark products (i.e. 'shark sanctuaries') (Friedman et al., 2018; Shiffman \& Hammerschlag, 2016).

\subsection{Managing risk through direct regulation}

Where they are in place, management measures for biological, technical and macro-economic risks tend to be implemented through direct regulation. Direct regulation focuses on mandating specific behaviours or outcomes, usually through technology, process or performance standards, and enforcement of their adoption. Technology standards focus on gear and equipment, while process standards relate to how technology is employed in a fishing operation (i.e. input-orientated). Performance standards focus on the outcomes of a fishing operation, such as catch or mortality (i.e. output-orientated). In the case of managing shark mortality, direct regulations may be imposed on the fishery causing shark mortality, or on the supply chain fuelling the fishery.

In fisheries, input-oriented instruments prescribe alterations to the fishing operation itself. Indeed, one of the most widely adopted approaches for shark conservation is direct regulation of fishing locations through marine reserves or shark no take zones (NTZs) (MacKeracher et al., 2018; Shiffman \& Hammerschlag, 2016; C. Ward-Paige \& Worm, 2017). Other input-orientated measures include regulation of fishing effort, or authorised gears and gear specifications. For example, the shark fisheries management plans for the North West Atlantic and Gulf of Mexico established gear restrictions to reduce bycatch/bycatch mortality, while all trawl nets in Western Australia are required to be fitted with bycatch reduction devices (Table 1). Fisheries regulations may also take the form of output-orientated policies, which are based on performance standards, such as the size or amount of catch. Examples include fishing quotas, such as those set for sandbar shark (Carcharhinus plumbeus) stocks in the Fishery Management Plan for Sharks of the Atlantic Ocean (Momigliano \& 
Harcourt, 2014), while the U.S. Atlantic Highly Migratory Species shark fishery has a total trip limit of 36 large coastal sharks, with several species managed as a species complex (Shiffman \& Hammerschlag, 2016). These policies may also restrict fishing for threatened species, through a low quota or fishing ban. For example, it is illegal to land whale sharks and manta rays in Indonesia, Malaysia and The Philippines (Friedman et al., 2018).

199

200

Macro-economic risks are most commonly managed through performance standards via trade controls, such as species-specific trade bans or low quotas for international export, or domestic bans on the sale of fins or on the commercial sale of all shark products (Friedman et al., 2018, Schiffman \& Hammershlag 2016). 


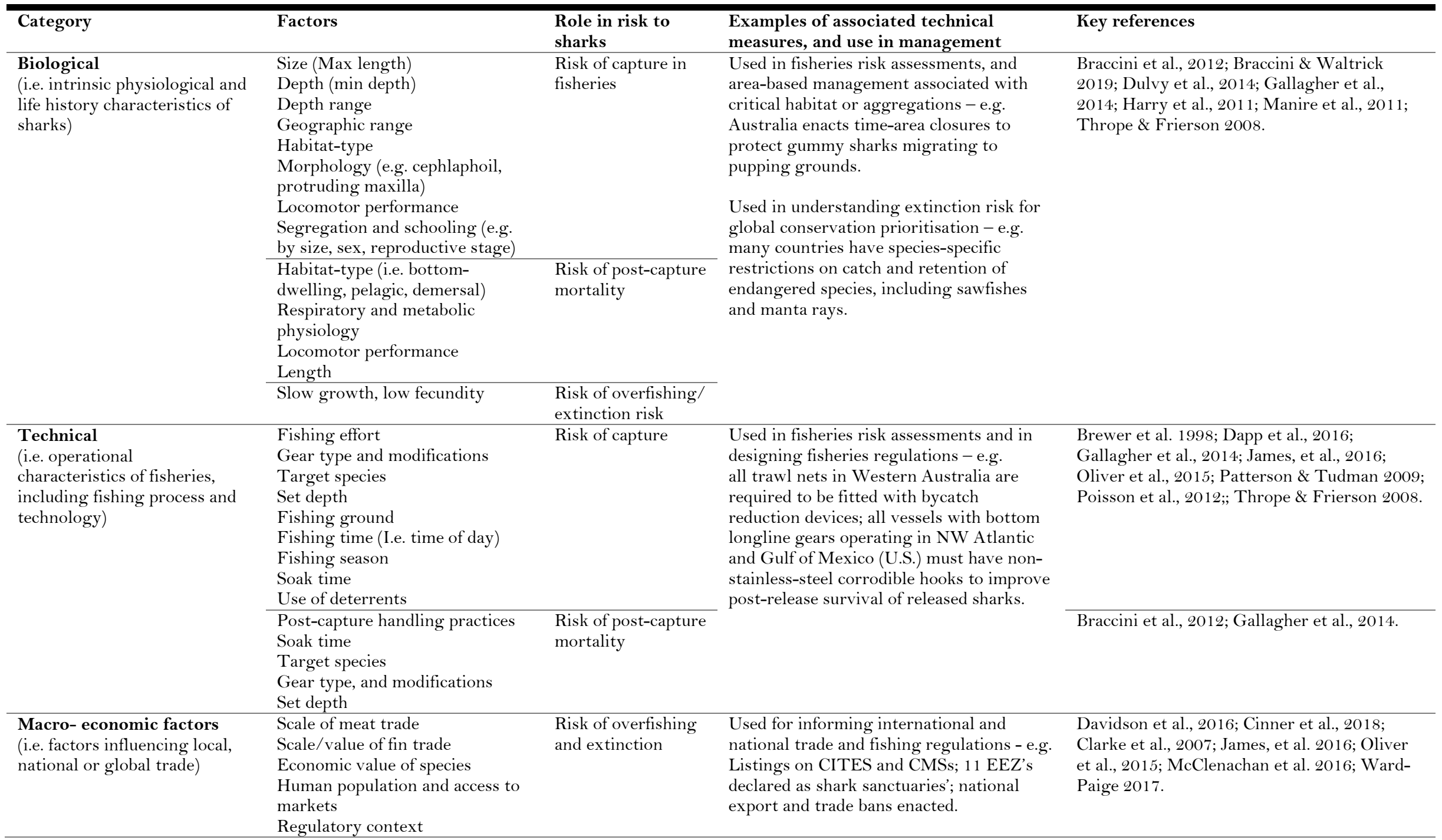

Table 1. Summary of biological, technical and macro-economic risks to sharks 


\section{The neglected complexities of managing shark mortality}

Implementing measures to address biological, technical and macro-economic risks can undoubtedly reduce fishing mortality and facilitate population recovery. For example, regulations in the Hawaiian longline swordfish fishery require vessels to use a specific combination of technical input controls, reduced shark bycatch by 36\% (Gilman et al. 2007); while science-based management of sandbar shark (Carcharhinus plumbeus) stocks in the U.S., involving quotas, permits, time-area closures and speciesspecific retention restrictions, has supported recovery of this species (Momigliano \& Harcourt, 2014).

However, these examples of success come from a handful of high-income countries (Schiffman \& Hammerschlag, 2016; Simpfendorfer \& Dulvy, 2016), which have significant resources and fisheries management infrastructures enabling them to develop and enforce science-based policies. However, this is an atypical context for much of the world's shark fishing pressure. The majority of global recorded shark production is derived from lower-income countries (Dent \& Clarke, 2014), which are dominated by diverse, unmonitored and unmanaged small-scale fisheries. These governments often possess limited resources for monitoring and compliance management; and uptake of available technical measures is limited (Momigliano \& Harcourt, 2014; Dulvy et al., 2017). Where management is in place, it tends to be relatively simplistic, with a focus on trade bans or total bans, and limited evidence to date of measurable reductions in shark mortality at the stock or fishery level (Shiffman \& Hammershlag, 2016; Friedman et al., 2018). Regulatory action is further complicated by the socioeconomic vulnerability of fishers, and their high dependence on marine resources for income, nutrition and well-being (Glaus et al., 2018; Golden et al., 2016; Jaiteh et al., 2016, 2017). In short, most approaches to shark management have been developed in a high-income country context, where scientific and resource capacity is high (Momigliano \& Harcourt, 2014; Simpfendorfer \& Dulvy, 2017). Yet in the highest priority countries for shark conservation, managing shark fishing is much more than a biological, technical and macro-economic issue; it is a human issue. Effective management in these contexts necessitates a holistic approach, which acknowledges the need to change human behaviour, foster compliance with rules, understand social and economic barriers to implementation, and consider human behaviour as a key source of uncertainty in fisheries management (Dutton \& 
Squires, 2008; Fulton, Smith, Smith, \& Van Putten, 2011; Milner-Gulland et al., 2018; Squires \& Garcia, 2018).

Current approaches for managing risks to sharks neglect these complexities through three implicit and interlinked assumptions (Figure 1):

Assumption 1: the mandated technical measure is the most effective measure that can be adopted to achieve the associated shark management goal.

Assumption 2: fishers, fishing fleets and industry have sufficient capacity and motivation to adopt these mandated measures. This assumption implies that fishers are willing and able to change their behaviour to take up these measures and comply with rules. Taking an instrumental perspective, this assumes that the (positive or negative) economic incentives created by direct regulation favour uptake and compliance, leading to:

Assumption 3: that shark mortality is driven primarily by economic incentives.

However, there is a wealth of evidence that these assumptions are flawed. While legal obligations can be a factor driving fisher behaviour, uptake of technical measures and compliance with regulations depend on a wide range of factors, which are often context-specific (Arias, 2015; Arias, Cinner, Jones, \& Pressey, 2015; Campbell \& Cornwell, 2008; Hall et al., 2007). Direct regulation rarely creates sufficient incentives to drive compliance, while economic incentives alone are rarely sufficient to change human behaviour (Campbell \& Cornwell, 2008; Dutton \& Squires, 2008; Hall et al., 2007; Milner-Gulland et al., 2018; Squires \& Garcia, 2014). This is especially pertinent to less marketoriented, lower technology fisheries, which are ubiquitous in the world's largest shark fishing nations, and often governed through local social norms and trust-based institutions (Grafton, 2005; Kosamu, 2015). 


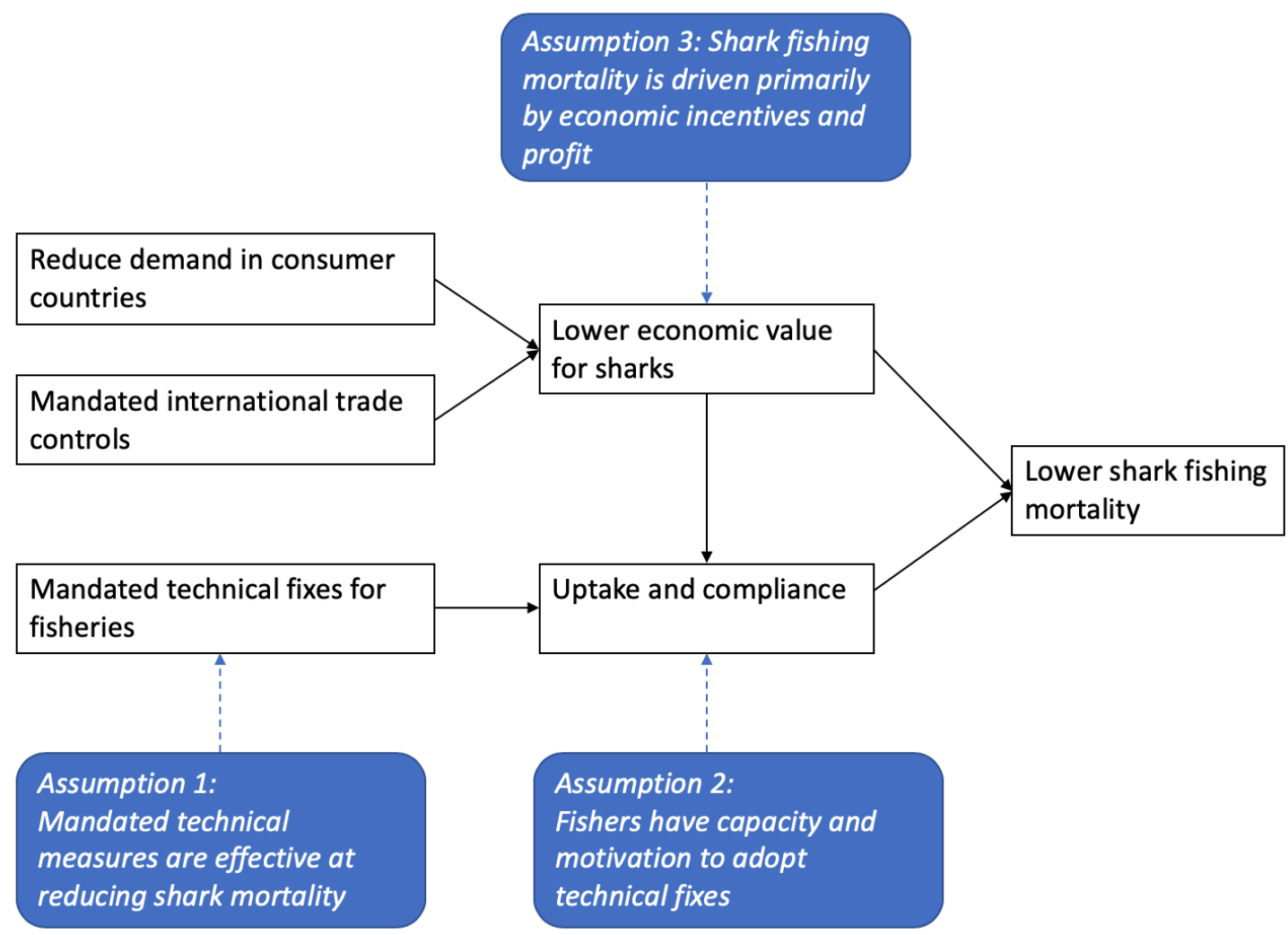

261

Figure 1. A simplified implied theory of change underlying current approaches to reducing shark fishing mortality through technical measures and macro-economic interventions

\subsection{Assumption 1: Technical measures are effective}

Shark management based on direct regulation assumes that the prescribed measure is the most effective approach for reducing risk to sharks in the regulated fishery and context (assumption 1). Yet this is not always the case. The appropriateness of several commonly-applied measures for shark management has been questioned (e.g. Shiffman \& Hammershlag 2016). Excessively prescriptive technical measures can be biologically ineffective, ecologically and socially problematic, difficult and costly to enforce, or insufficiently robust to dynamic changes in the ocean and its users (Jaiteh et al., 2016; MacKeracher et al., 2018; Maxwell et al., 2015; Shiffman \& Hammerschlag, 2016; Tolotti et al., 2015).

\subsubsection{Ineffective measures}

There are several examples of existing mandated measures for shark management that may be of limited effectiveness for reducing fishing mortality. For example, spatial closures are one of the most 
widely advocated and adopted strategies for shark management (MacKeracher et al., 2018). Spatial closures can come in the form of species- or complex-specific time-area closures, though are commonly applied in the form of general no-take marine reserves (MPAs) or nationwide 'shark sanctuaries'. However, while these approaches represent conceptually-appealing policy wins, the benefits of MPAs for sharks remains questionable. Benefits are likely to be limited to a small number of coastal, smallranging species or specific life history stages (Jaiteh et al., 2016; Knip, Heupel, \& Simpfendorfer, 2012; Yates, Tobin, Heupel, \& Simpfendorfer, 2016), while benefits to larger more migratory species, which are often those in need of more urgent conservation action, are rare (Graham et al., 2016; HoweyJordan et al., 2013). Even within some large MPAs, shark populations continue to decline (Graham, Spalding, \& Sheppard, 2010; White, Myers, Flemming, \& Baum, 2015). This may be due to insufficient enforcement leading to continued fishing within MPAs (Carr et al., 2013), or displacement of fishing effort to other places, species or life history stages, with sharks remaining vulnerable to fishing pressure in the parts of their range outside of MPAs (O'Keefe, Cadrin, \& Stokesbury, 2014). Spatial closures for sharks can also lead to unintended negative social consequences (Jaiteh et al., 2016), with social issues often neglected, despite the wide-held belief that social outcomes are essential for enhancing the benefits of MPAs to sharks (MacKeracher et al., 2018).

Similarly, species-specific or total bans are not always effective, because implementation at the point of catch depends on target species, gear and the shark species of management concern. In many fisheries, a certain level of incidental shark catch is unavoidable, and sharks may already be dead or dying before release is feasible, rendering a total ban biologically ineffective (Gallagher et al., 2014; Braccini \& Waltrick, 2019; Tolotti et al., 2015). This is particularly problematic for highly mobile pelagic species which exhibit ram ventilation, such as scalloped hammerhead sharks (Sphyrna lewini), spinner sharks (Carcharhinus brevipinna), mako sharks (Isurus spp.) and thresher sharks (Alopias spp.). These species are commonly caught as incidental catch in longline and purse seine fisheries, and have very high levels of post-capture mortality (Gallagher et al., 2014, Braccini \& Waltrick, 2019). As such, blanket bans need to be accompanied with practical fisheries management measures that effectively avoid or minimise capture, or promote live release, based on what is feasible for a given species or 
fishery. In general, 'one-size-fits-all' approaches, which apply one set of prescribed rules to sharks as a homogenous species-group, are of limited effect in practice (Dulvy et al., 2017; Shiffman \& Hammershlag, 2016). Differences in life history strategies and susceptibility to fishing will influence the effectiveness of different management strategies for different species (Braccini \& Waltrick, 2019; Harry et al., 2011; Yates et al., 2016). The consequences of ineffective measures can also have widerreaching impacts on management, through affecting perceived legitimacy and the likelihood of uptake by fishers (Hall et al., 2007, See Assumption 3).

Prescriptive technical measures also fail to consider that the effectiveness of a measure will vary based on fine-scale biophysical characteristics within a fishery or fishing trip, such as temperature, season and time of day (Maxwell et al., 2015). Research has shown that the effectiveness of some technical measures (e.g. leader lines and hook types) varies in space, time and under different operational and environmental circumstances, as well for different shark species (Branstetter \& Musick, 1993; Bromhead et al., 2012; Cooke \& Suski, 2004; Serafy, Orbesen, Snodgrass, Beerkircher, \& Walter, 2012). In many cases, there is a need for dynamic decision-making at sea, based on prevailing biophysical conditions (Maxwell et al., 2015). As such, if appropriately incentivised, fishers themselves may have better information for making optimal, adaptive decisions, rather than behaviour being prescribed (Hall et al., 2007).

\section{There are also examples where technical measures, such as preventing daylight setting of gear or} outright fishery closures, have unintentionally increased levels of bycatch for either the species they are attempting to protect (Sarmiento, 2006) or other species of conservation concern (Baum et al., 2003; Weimerskirch, Catard, Prince, Cherel, \& Croxall, 1999). Unintended consequences can also occur at the macro-economic level, with bans creating black markets, and in some cases stimulating demand for more rare, luxurious and high-price commodities. Effectiveness depends on monitoring and enforcement capacity, as well as the nature of demand in consumer markets (Challender, Harrop, \& MacMillan, 2015; Courchamp et al., 2006; Hall, Milner-Gulland, \& Courchamp, 2008). 


\subsection{Assumption 2: Capacity and motivation for adoption}

Mandated measures assume that fishers, fishing fleets and industry have sufficient capacity and motivation to adopt them (Assumption 2). That is, they are willing and able to change fishing behaviour and decision-making to uptake measures and comply with rules. However, if technical measures for shark management are to be adopted in practice, they need to be appropriately incentivised, either positively (e.g. through economic benefits) or negatively (e.g. through enforcement and putative action), with efforts to ensure that such measures are as cost- effective as possible (Gjertsen, Squires \& Eguchi, 2014; Hall et al., 2007; Hilborn, Orensanz, \& Parma, 2005). These factors are rarely considered in contemporary shark management design, or indeed in bycatch reduction research more broadly (Campbell \& Cornwell, 2008). Yet failure to consider them can result in unacceptable implementation costs and negative socioeconomic impacts to fishers and fishing fleets (Innes \& Pascoe, 2008; Jaiteh et al., 2016; O’Keefe et al., 2014; Rausser, Hamilton, Kovach, \& Stifter, 2009), in turn leading to a lack of compliance and implementation failure (Fulton et al., 2011; Gezelius, 2002).

\subsubsection{Unrealised benefits}

In bycatch reduction literature, positive economic incentives are believed to arise through a range of efficiencies (Campbell \& Cornwell 2008). Examples include: less time sorting unwanted or low value catch (Broadhurst, 2000; Fonseca, Campos, Larsen, Borges, \& Erzini, 2005); less damage to gear (Bache, 2003; Brewer, Rawlinson, Eayrs, \& Burridge, 1998); higher total value of catch/catch per unit effort because bait, space and trips are not taken up by non-target catch (Fonseca et al., 2005; Gilman, Boggs, \& Brothers, 2003; Gilman, Dalzell, \& Martin, 2006); and potential for higher sales value through marketing eco- friendly seafood (Bache, 2000; Gilman, Brothers, \& Kobayashi, 2005). However, the benefits of technical measures demonstrated in theory or under research conditions may not be replicated in practice. For example, bycatch reduction devices can be cumbersome, difficult to introduce and operate, and may malfunction or be costly to maintain (Campbell \& Cornwell, 2008; Hall et al., 2007; Kaplan, Cox, \& Kitchell, 2007). What is more, any benefits may be 
captured further up the supply chain, by boat owners or investors, as opposed to the fishers implementing the measures. These benefits are even harder to realise for sharks, since sharks are often valuable, marketable catch.

\subsubsection{Hidden costs}

As well as unrealized benefits, some measures may be unacceptably costly to implement, due to foregone catches and revenues. For example, introduction of by-catch reduction technologies (BRTs) in the Gulf of Mexico shrimp fishery resulted in significant shrimp loss (Margavio \& Forsyth, 1996), while input controls in the Hawaiian longline fishery reduced bycatch, but also caused significant reduction in catch rates for tunas and several other commercial species (Gilman et al., 2007). Such opportunity costs are particularly relevant for shark management, where species of conservation concern may have a high market value. For example, a semi-commercial pelagic shark fishery in Indonesia takes a mixture of species, which include species of low fecundity and international management concern such as hammerheads (Sphyrna spp.) and silky sharks (Carcharius falciformes), and species with higher productivity such as blue sharks (Prionace glauca), milk sharks (Rhizoprionodon acutus) and dogfish (Squalidae sp.) (Yulianto et al., 2018). While it may be desirable from a conservation perspective to reduce catch of hammerhead sharks and silky sharks, these species are also some of the most economically valuable in the fishery (Lestari et al., 2016). Limiting catch of these species would result in a significant decline in total catch value, and in turn household income, for fishers and traders in this community. Similarly, even species reportedly taken as bycatch in non-target fisheries represent considerable economic value. For example, several smallscale coastal gill net fisheries in Indonesia, which target shrimp and small demersal teleosts, also incidentally take wedgefishes (Rhinidae spp.). Yet despite being a small volume of the total catch, wedgefishes can make up a significant proportion of total catch value, since their market value is extremely high relative to other species (Hau, Abercrombie, Ho, \& Shea, 2018).

In the absence of market-based incentives for sustainable management, or alternative sustainable income streams, management can lead to unacceptable negative consequences. These may be socio- 
economic, in terms of reduced income, employment, and food security; or ecological, with displacement of effort towards other vulnerable or overexploited species and stocks. For example, area-based restrictions and declining fin prices in Eastern Indonesia reportedly displaced small-scale fishers, and drove uptake of risky, illegal income generation activities, such as people smuggling (Jaiteh et al., 2016). While a ban on manta ray fishing resulted in a three-fold increases in devil ray catch in one fishery in Indonesia, due to a shift in effort to non-protected species (S Lewis pers. comm, Misool Foundation unpublished data). It is also plausible that regulation-induced declines in market value for silky sharks (Carcharius falciformes), hammerhead sharks (Sphyrna spp.) and other CITES-listed species, could drive an increase in shark fishing pressure to replace lost economic value. For example, in a socio-economic survey of shark fishers in Tanjung Luar, Indonesia, $75 \%$ of fishers stated that they would continue to fish as normal or increase their fishing effort, should their shark catch decline, rather than change target species or livelihood (Lestari et al., 2016). Other intangible costs, such as a loss of cultural values, may also be common (see Assumption 3, section $4.3)$.

Identifying and understanding the costs of shark management is further complicated by the mixed capture of multiple species; the fuzzy distinction between target and bycatch in small-scale tropical fisheries; and the fluid and often opportunistic nature of fishing within the broader livelihood strategies of rural coastal communities (Allison \& Ellis, 2001; Bene, 2006; Carter \& Garaway, 2014). Many small-scale fishing communities, particularly in lower-income countries, already face structural poverty and vulnerability to shocks, with instable income and high reliance on marine resources for nutrition and food security (Golden et al., 2016). In these communities, sharks are not only caught to generate income, but also for food, providing an important source of animal protein and micronutrients, particularly as catches in traditional food fishes decline (Glaus et al., 2018, Golden et al., 2016). Fishing can therefore serve an important welfare function, such as creating a labour buffer or safety net for structurally poor or vulnerable households (Bene, 2006; Jul-Larsen, Kolding, Overå, Nielsen, \& Zwieten, 2003). As such, some costs of shark management may be hidden or intangible, such as increased vulnerability to shocks or reduced access to micronutrients, and may disproportionally affect poor households. If predicated on an incomplete understanding of 
livelihoods and the pro-poor functions of small-scale fisheries, management measures may be incompatible with both conservation and the social and economic goals of fisheries management (Allison \& Ellis, 2001). This underlines the practical and ethical impetus to consider the direct and indirect opportunity costs to fishers when designing management approaches.

\subsubsection{The limitations of enforcement}

Incentives may also be negative, through to the costs - theoretical, actual and perceived - of enforcement. When technical measures are mandated, enforcement is assumed to incentivize uptake through avoidance of putative action. While there is empirical evidence that risk of enforcement plays some role in shaping fisher behaviour (Arias et al., 2015), little attention has been paid to what kinds of regulations produce economic incentives for uptake, the investments required in monitoring and enforcement to ensure compliance (and whether these are realistic, given budgetary constraints), and in what ways they function in the contexts of different shark fisheries.

Economic models theorize that the cost of enforcement is a function of probability of an act of noncompliance being detected and punished, and the severity of punishment that results (Becker, 1968). This suggests that penalties must at least balance the illegal gains from catch, the threat of enforcement must be credible, and that cost-effective monitoring information is available for detecting non-compliance. However, shark catch can be highly valuable (e.g. Hau et al., 2018), penalties in fisheries law can be weak, and managers and other fishers may be reluctant to deliver strong sanctions against non-compliant fishers for social or cultural reasons (Gezelius, 2002). Fisheries enforcement often fails in practice because of low detection probabilities in extensive and remote fishing grounds, which are monitored by enforcement agencies with limited resources (Gilman et al., 2003). This is exacerbated in small-scale fisheries, which are ubiquitous in the coastal waters of low-income countries, and almost entirely unregistered and unmonitored. Regulatory action in these contexts is further complicated by the socio-economic vulnerability of fishers, with ethical concerns and limited political will to strictly enforce laws. 
Even in a world of high detection probabilities and severe penalties, the costs of enforcement may fail to incentivize sustainability or change behaviour in the desired way. Fishers may respond by taking measures to avoid putative enforcement action rather than to fish more sustainably. For example, mandated by-catch reduction technology (BRT) in a shrimp fishery in Texas led to fishers attempting to 'beat the system' by tying off their BRTs in the water, looking for loopholes in the regulations and simply not employing BRTs until caught without them (Jenkins, 2006). These situations can create costly 'arms races' between enforcement agencies and fishers (Campbell \& Cornwell, 2008).

Overall, the negative incentives created by enforcement can support uptake of technical measures, but only when the probability and costs of being caught are high, and even then, only to a certain point (Arias, 2015; Jenkins, 2006). The success of enforcement will be influenced by the specifics of the fishery, the measure being regulated, and the socio-economic context.

Ultimately, the incentives for adopting a fisheries management measure will depend on a complicated balance of costs and benefits. These include: the benefits arising through catch efficiencies and market-based rewards, the fixed and variable economic costs of adopting and maintaining a technical measure, the opportunity cost of lost valuable catch, and the risk and cost of enforcement; as well as other hidden or intangible costs that may arise (See Assumption 3).

\subsection{Assumption 3: Economic incentives are sufficient}

Finally, even in cases where prescribed technical measures are seemingly effective and sufficiently incentivised, they may not be widely implemented (Damalas \& Vassilopoulou, 2013; Orphanides \& Palka, 2013; Radzio, Smolinsky, \& Roosenburg, 2013). As such, even if they do exist, shark fishers may not respond to incentives by reducing catch (Assumption 3). This is because economic models of how people make decisions are unrealistic - "Individuals may have bounded rationality, limited by cognitive resources, and employ a variety of heuristic procedures to achieve outcomes that are 'good enough' rather than truly optimal" (Conlisk 1996). A range of emotional, social, cultural and 
cognitive biases shape people's decisions (Cinner, 2018), thus influencing uptake of technical measures and compliance with regulations. What is more, extrinsic incentives can have complex interactions with social norms and intrinsic motivations. As such, introducing extrinsic motivations in an unsuitable social context can create conflicts between different types of motivations, and lead to unexpected or unintended impacts on behaviour. For example, economic incentives can crowd-in or crowd-out intrinsic motivations for prosocial behaviour, or damage trust and institutions (Bowles \& Polanía-Reyes, 2019; Gneezy, Meier, \& Rey-Biel, 2011). Understanding the decision-making context is therefore crucial for designing suitable management interventions, which can effectively modify fisher behaviour in the desired direction, improve management outcomes and reduce regulatory costs (Grafton, 2005).

(1)

6

\subsubsection{Cognitive biases}

Lessons from the field of behavioural economics indicate that that responses to incentives are shaped by mental heuristics, such as loss aversion, as opposed to rational costs-benefit calculations.

Therefore, the framing of an issue or incentive can be more important than its absolute magnitude (Cinner, 2018; Hossain \& List, 2012). Symbolic or social rewards may also be more effective and efficient at encouraging a desired behaviour than direct economic incentives, particularly in a public goods or social context (Gallus, 2017; Pentland, 2014). People often act in ways that are shaped by sub-conscious cues, such as emotional associations, ego, priming or anchoring. Decisions are also strongly influenced by social context, such as who communicates information to them (e.g. trusted messengers and block leaders), what they normally do (e.g. the status quo bias), what most people do (e.g. peer pressure and social norms), and what other people see (e.g. observability) and expect of them (e.g. public commitments, reputation and recognition) (Abrahamse \& Steg, 2013; Cinner, 2018; Gallus, 2017; Mbaru \& Barnes, 2017; Thaler, 2018).

\subsubsection{Social influences}

Research into the social aspects of fisheries management has shown that social networks; trust and social capital; local leadership and role models; institutional structures; social norms and peer 
pressure; perceived legitimacy of regulations; perceived effectiveness of proposed measures; and even the skill, experience and motivation of individual fishers and captains shape uptake of technical measures (Barnes, Lynham, Kalberg, \& Leung, 2016; Gutiérrez, Hilborn, \& Defeo, 201 1; Hall et al., 2007; Mbaru \& Barnes, 2017).

For example, social networks have been identified as a key factor in shaping uptake of shark bycatch mitigation measures in Hawaii's tuna longline fishery (Barnes et al., 2016). While in Indonesia, many shark fishers inherit their gears and fishing practices from their fathers and grandfathers, and take considerable pride in their way of life (Lestari et al., 2016). As such, adopting shark management measure may violate social and cultural norms, which can lead to widespread noncompliance (e.g. Gezelius, 2002). Similarly, Margavio and Forsyth (1996) described how resistance of shrimp fishers to mandated BRTs in Louisinana, USA was a manifestation of defence of traditional cultural practices, fear of eroding independence, and anger at the marginalization of shrimping in the face of competing economic activities. These issues are analogous to those documented in the human-wildlife conflict literature, where social factors, intangible costs or underlying human-human conflicts may be more important for effectively resolving conflict than technical measures (Dickman, 2010; Redpath et al., 2013; Thirgood \& Redpath, 2008).

In identifying opportunities for engaging people in land-based conservation, Knight et al. (2010) and Selinske et al. (2015) also found that human and social capital defined people's willingness to engage. The most salient factors included conservation knowledge, entrepreneurial orientation, local sense of belonging or attachment, confidence in governance, local networks, willingness to collaborate and social learning (Knight, Cowling, Difford, \& Campbell, 2010; Selinske, Coetzee, Purnell, \& Knight, 2015). Human capital may be similarly important for engaging fishers in adopting shark fisheries management measures. Fishers and skippers are known to differ in their knowledge, experience, risk tolerance, and ability or willingness to adjust, such that imposing the same standard on all vessels does not necessarily achieve optimal management goals in an efficient, least-cost manner (Hall et al., 2007; Squires \& Garcia, 2018). Management measures that acknowledge and capitalize on this heterogeneity have a greater chance of being accepted, and achieving socially efficient outcomes 
(Hall et al., 2007; Knight et al., 2010; Squires \& Garcia, 2018). In many cases, fishers themselves, as opposed to policy-makers, may also be better placed to make the most effective fishing decisions to avoid shark catch in a given time or place, given their large repository of practical knowledge and experience (Hall et al., 2007). Similarly, the perceived legitimacy of a rule, in terms of its effectiveness, justness and confidence in regulating institutions, can affect uptake and compliance (Hall et al., 2007; Levi, Sacks, \& Tyler, 2009; McClanahan, Marnane, Cinner, \& Kiene, 2006; Tyler, 1990). Lessons from bycatch mitigation efforts for other species indicate that fishers need to understand the importance of the management problem, and believe that proposed solutions are effective (Hall et al. 2007). Failing to recognise fisher knowledge or getting a technical measure wrong may therefore damage perceived legitimacy of a regulation or regulating institution, and negatively impact management efforts.

In addition, local institutional context and tenure regimes influence the success of fisheries management (Hilborn et al., 2005). Community-based management interventions that engage with local or traditional institutions, build upon cultural values, provide rewards and equitable benefit distribution, and provide opportunities for social learning are more likely to succeed (Brooks, Waylen, \& Borgerhoff Mulder, 2012; Hilborn et al., 2005; Oldekop, Bebbington, Brockington, \& Preziosi, 2010; Waylen, Fischer, Mcgowan, Thirgood, \& Milner-Gulland, 2010). Compliance can also emerge and persist through group dynamics if individuals cooperate and enforce rules by social pressure (Fehr \& Gachter, 2002; Fowler, 2005); or can break down where rules do not align with the social norms of the group (Gezelius, 2002). As such, novel policy instruments, such as performancebased incentives that foster peer pressure and group-level cooperation, may be more efficient and effective than direct regulation and enforcement (Fehr \& Gächter, 2002; Gezelius, 2002; Keane, Jones, Edwards-Jones, \& Milner-Gulland, 2008) (Gezelius, 2002; Fehr \& Gachter, 2002; Keane et al., 2008). What is more, since social context is dynamic, different factors may be responsible for encouraging initial uptake of management measures, and maintaining use and engagement in the long-term (Selinske et al., 2015). 
Social-psychological models of human behaviour consider that a combination of behavioural beliefs, based on the evaluation of a likely outcome of a behaviour; normative beliefs, based on perceptions about how others will judge a behaviour; and perceived behavioural control, based on perceptions of self-efficacy and autonomy with regard to a behaviour, are crucial in shaping behavioural intentions. This behavioural intention is in turn moderated by intervening factors, which may create barriers to a behaviour even when a behavioural intention exists. Individuals may have multiple evaluations of a behaviour, some of which will be more salient than others (the Theory of Reasoned Action and the Theory of Planned Behaviour (Ajzen, 1991; Fishbein \& Ajzen, 1975), see also norm activation theory, social norm, theory and self-determination theory). These models recognize that a combination of instrumental and normative, and extrinsic and intrinsic factors will shape behavioural intentions and outcomes (Deci \& Ryan, 1985; Ryan \& Deci, 2002).

In addition to theory, social psychology methods, such as psychometric surveys, have been applied to conservation planning to understand motivations of individual resources users at the local level (Knight et al., 2010; Selinske et al., 2015, 2019), and to design and tailor policies and instruments, such as financial incentives, to meet diverse motivations of individual resources users (Selinske et al., 2017).

\subsection{The socio-economic implementation gap}

Overall, we have demonstrated that managing shark fishing is much more than a biological and technical issue: it is a human issue. The need to consider human issues is not new to conservation, yet it has been neglected in shark science and management (Simpfendorfer et al., 2011, Dulvy et al., 2017). We argue this is creating a socio-economic implementation gap (Figure 2), which hinders effective management, and is particularly problematic for developing countries that are dominated by small-scale mixed-species fisheries. We have demonstrated there is a practical and ethical imperative to consider socio-economic issues, which echoes earlier calls for research in to the social and economic aspects of shark fisheries (e.g. Simpfendorfer et al., 2011, Dharmadi et al., 2015). What 
is more, socio-economic issues may be even more relevant to shark conservation than many other fields, due to the mixed fisheries, diverse contexts, conflicting human uses and values, and complex supply chains, which play a role in food and livelihood security in poor and developing nations.

The complexities discussed here demonstrate that fisheries need to be managed within their specific ecological, economic and social contexts, using a complementary mix of policies and instruments, which seek to converge the behavioural motivations and welfare of fishers, with conservation objectives (Brady \& Waldo, 2009; Fulton et al., 2011). These policies and instruments must also be consistent with cost-effective monitoring and enforcement. Accordingly, there is a need to differentiate between different fishery types, and the primary drivers of shark fishing mortality in each fishery, when making management decisions. For example, differentiating between industrialscale fishing for profit, small-scale commercial fishing for food and profit, and subsistence fishing for food only; as well as between fisheries that take sharks as primary catch, valuable secondary fishing, or true bycatch. Understanding these drivers will be critical for designing management measures that are effective at reducing shark fishing mortality, whilst appropriately considering the needs and capacities of people (Barker \& Schluessel, 2005; Dharmadi et al., 2015; Glaus et al., 2018). Further, an increased understanding of the attitudes, norms and underlying motivations of fishers, and their interactions and dynamics as a group, is needed to design policy instruments that can effectively change fishing behavior (Ajzen, 1991; Battista et al., 2018; Milner-Gulland et al., 2018; Stern, 2018). The heterogeneity, dynamism and stochasticity of these socio-economic contexts implies that we should not expect to find simple, generalizable solutions. Rather, we should seek measures that are adequate for the local socioeconomic and institutional realities (Waylen et al. 2010).

Moving forwards, achieving much-needed reductions in global shark fishing mortality will require researchers and practitioners to take a more holistic approach to risk-based management and decision-making (Figures $2 \& 3$ ). Such an approach needs to consider not only the biological and technical aspects of species and fisheries, but also the feasibility of management actions, given the socio-economic context. Explicit assessment of feasibility can support the design of management measures, and complementary policies and instruments, which are tailored towards to the 
617 characteristics of individual places and people. This can help to ensure management measures are

618 effective and ethical, and thus overcome the socio-economic implementation gap (Ostrom et al. 2007,

619 Knight et al. 2010).

620

621 A holistic approach to risk will be particularly important for delivering shark conservation outcomes

622 in lower income countries, where shark fisheries management measures will need to address

623 multiple objectives and manage difficult trade-offs, such as: protection of the most vulnerable shark

624 species, sustainable offtake of co-occurring species and populations that can withstand it (shark and

625 non-shark), and maintenance of the livelihoods and well-being of vulnerable coastal communities. 


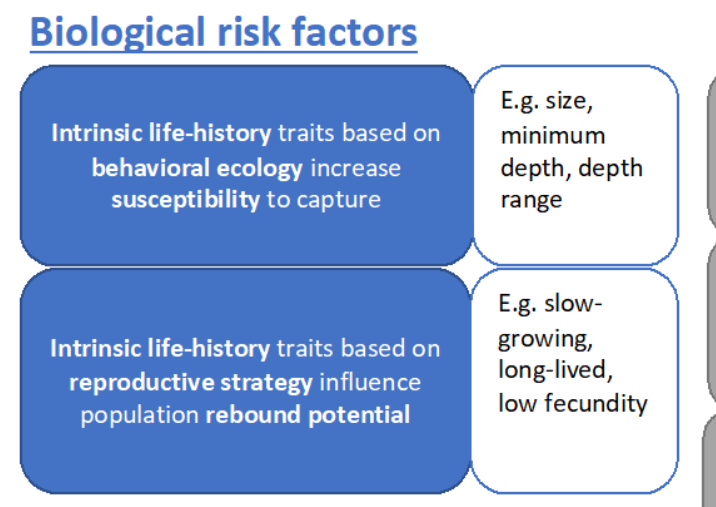

\section{Technical risk factors}

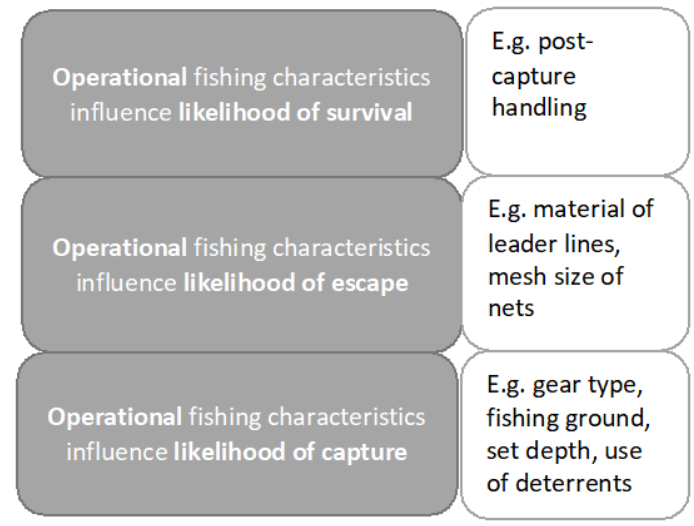

Macro-economic risk factors
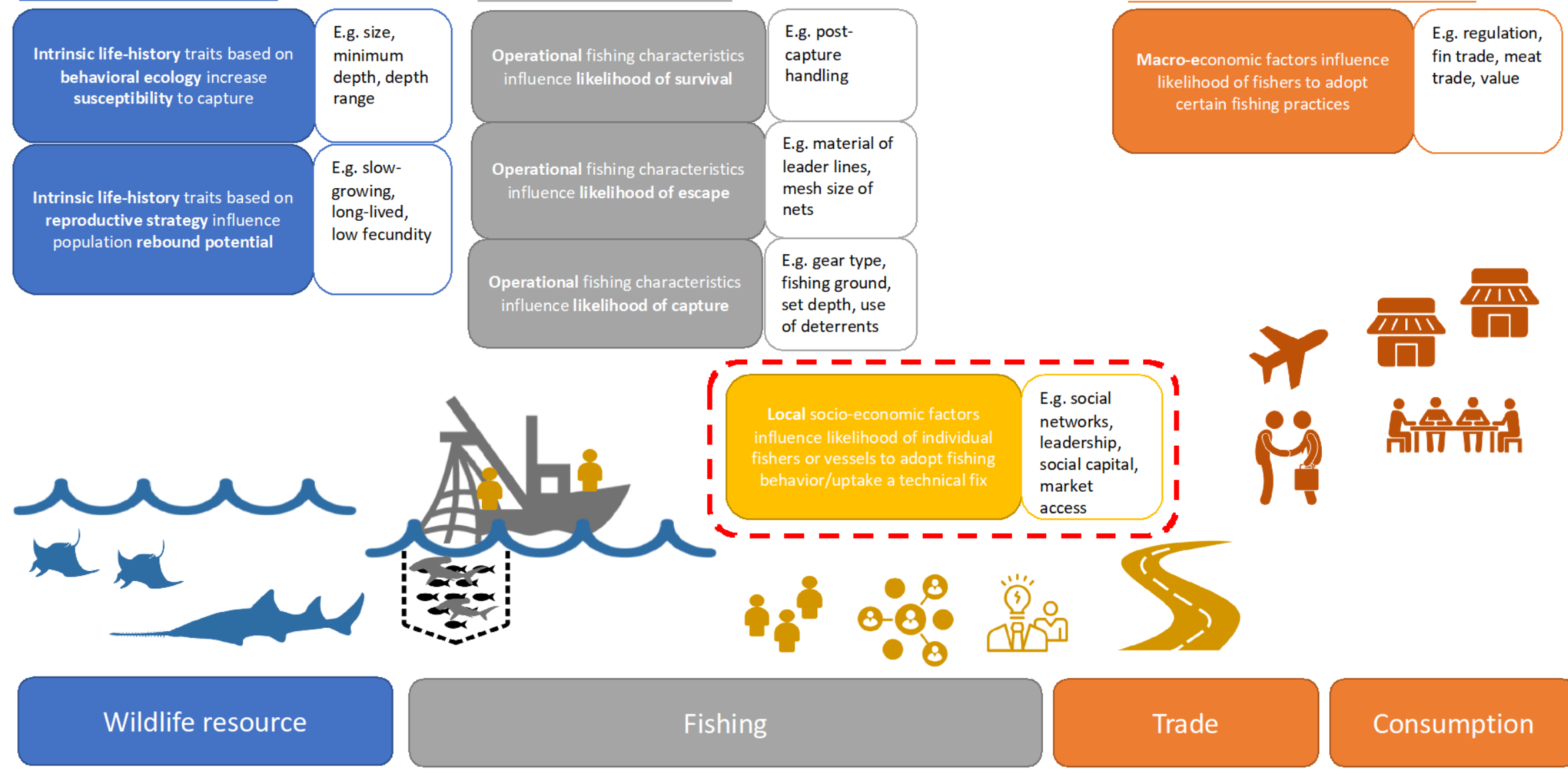

Mandated technical fixes for fisheries

\section{Fishing}

Trade

Consumption

Figure 2. A conceptual diagram of all risk factors to sharks throughout the shark trade chain, with highlighted gaps in management related to local-/micro-scale socio-economic factors 
630

631

632

633

634

635

636

637

638

639

640

641

642

643

644

645

646

647

648

649

650

651

652

653

654

655

\section{Priorities for holistic risk-based shark management: bridging the}

\section{socio-economic implementation gap}

Going forwards, we propose several priorities for bridging the socio-economic implementation gap for shark management. In particular, we propose that feasibility assessments be explicitly incorporated in to fisheries risk assessments and decision-making processes. To support this, a deeper understanding of the human dimensions of shark fisheries is required, alongside holistic management frameworks that support the integration of socio-economic considerations from planning to implementation to monitoring.

\subsection{Feasibility assessments}

A holistic approach to understanding and managing shark fisheries requires that socio-economic factors and implementation costs be integrated throughout risk assessment processes. This is not a new concept in conservation, with a substantial body of literature on the importance of incorporating cost and feasibility in to systematic conservation planning (Natalie C. Ban, Hansen, Jones, \& Vincent, 2009; Natalie Corinna Ban \& Klein, 2009; Zhang \& Vincent, 2019), and on evaluating the impacts of conservation interventions on human well-being (Bull, Baker, Griffiths, Jones, \& Milner-Gulland, 2018; Milner-Gulland et al., 2014; Woodhouse et al., 2015). Yet these concepts are yet to be adopted and adapted to shark fisheries management. To do so, we suggest the addition of a new dimension to traditional risk assessments for sharks: feasibility (Figure 3). While these considerations may add an additional layer of complexity to an already complex problem (Dulvy et al., 2017), there are various established methods for the integration of socio-economic variables in to decision-making and management, which could be adapted for this purpose (Álvarez-Romero et al., 2018). For example, Davidson and Dulvy (2017) used a national-level conservation likelihood score for prioritising shark management needs for different countries (Dulvy et al., 2017), while Knight et al. (2010) used five dimensions of conservation opportunity to schedule conservation action at the ecosystem-level. 
Building on this, we propose six potential dimensions of feasibility for shark management. These include economics and well-being, which are associated with the monetary and non-monetary costs of shark management; while human capital, social capital, regulation and governance, and human pressure relate to the broader enabling environment. Each dimension may have multiple constituent components, which in turn can have positive or negative impacts on feasibility, depending on the context of the fishery (Table 3). Economics includes the direct economic costs and benefits of adopting a management measure, in terms of losses or gains in catch and associated income, and the costs of putative action through enforcement. Well-being includes broader costs and benefits to people beyond changes in income, such as basic needs (e.g. food security, employment security, access to services); agency (e.g. participation in decision-making); and experienced quality of life (e.g. ability to pursue goals) (Bull et al., 2018). Human capital includes knowledge, skills and experience of fisher communities, and their access to technology and tools, which influence the capacity to uptake a management measure. Social capital includes social influences that may enable or disable implementation, such as social networks, leadership, local institutions, willingness to collaborate, peer pressure, public perceptions and trust. Regulation and governance include factors within the broader regulatory context, such as policy frameworks to protect species or control trade, and how well these are implemented, through government effectiveness and rule of law (Table 3). Finally, human pressure relates to broader scale market and subsistence pressures on a fishery, such as gravity of human impacts, based on human population and travel time (Cinner et al., 2018). This list is not necessarily exhaustive, and the most important factors would need to be identified and assessed based on the context of a given fishery. For example, factors such as food security, livelihoods, poverty and corruption will be less important in high-value commercial fisheries in wealthy, politically stable developed countries such as Australia and the USA, while they may be critical in defining the effectiveness of a management measure in a small-scale coastal fishery in a developing country such as India or Indonesia.

Once key feasibility issues are identified, quantitative or semi-quantitative assessments of the risk they pose could be conducted, to determine a feasibility score. This information can then be used to supplement traditional risk assessments, for example through adding a third 'feasibility' dimension to 
685 Productivity-Susceptibility Analyses (PSA) (Figure 3). In some cases, it may be challenging to gather 686 quantitative data on all of these factors, and the magnitude of the risk they pose. As such, a ranking, 687 scoring or categorisation system could be adopted based on informed judgement or expert elicitation. 688 These methods are commonly used for ecological risk assessments in data poor contexts (Beauvais, 689 Zuther, Villeneuve, Kock, \& Guitian, 2018; Mace et al., 2008), and are already used for semi690 quantitative biological and technical risk scores in PSAs, e.g. through 1-3 or high-to-low scoring 691 systems (Gallagher et al., 2012; Hobday et al., 2007).

692

693 Overall, the adoption of feasibility and its explicit assessment alongside biological and technical 694 factors would enable a more holistic understanding of risks to sharks in fisheries. This would build on 695 a substantial body of work to systematically include socio-economic factors in conservation planning 696 (Álvarez-Romero et al., 2018; Knight et al., 2010; Polasky, 2008), and address recent calls to include 697 local people in conservation planning for sharks (MacKracher et al., 2018, Rigby et al., 2019).

698 


\begin{tabular}{|c|c|c|c|c|c|c|c|}
\hline & & \multicolumn{2}{|l|}{ Costs and benefits } & \multicolumn{4}{|c|}{ Enabling or disabling environment } \\
\hline & & Economics & Well--being & Human capital & Social capital & $\begin{array}{l}\text { Regulation and } \\
\text { governance }\end{array}$ & Human pressure \\
\hline 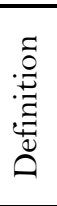 & & $\begin{array}{l}\text { Economic gains or losses } \\
\text { of adopting management } \\
\text { measures }\end{array}$ & $\begin{array}{l}\text { Well-being gains or } \\
\text { losses of adopting } \\
\text { management } \\
\text { measure }\end{array}$ & $\begin{array}{l}\text { Knowledge, skills, and } \\
\text { experience of fisher } \\
\text { community, and } \\
\text { availability of } \\
\text { tools/technologies }\end{array}$ & $\begin{array}{l}\text { Networks, } \\
\text { relationships and } \\
\text { cohesion within fisher } \\
\text { community }\end{array}$ & $\begin{array}{l}\text { Policies, rules, official } \\
\text { institutions, and their } \\
\text { implementation }\end{array}$ & $\begin{array}{l}\text { Broader scale market } \\
\text { and subsistence } \\
\text { pressures }\end{array}$ \\
\hline \multirow[b]{2}{*}{ 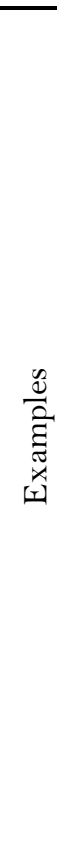 } & 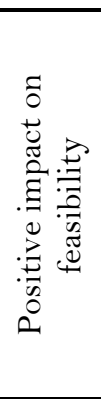 & $\begin{array}{ll}- & \text { Increase in target } \\
\text { catch } \\
- & \text { Increased value of } \\
& \text { target catch } \\
- & \text { Avoidance of costly } \\
\text { putative measures } \\
-\quad & \text { Lower operational } \\
\text { costs/operational } \\
\text { efficiencies } \\
- & \text { Incentives }\end{array}$ & $\begin{array}{ll}- & \text { Increase in food } \\
\text { - } & \text { security } \\
\text { Increase in } \\
\text { employment } \\
\text { security } \\
-\quad \text { Increase in } \\
\text { access to other } \\
\text { services }\end{array}$ & $\begin{array}{ll}\text { - } & \text { Conservation } \\
& \text { values } \\
\text { - } & \text { Desire to learn }\end{array}$ & \multirow{2}{*}{$\begin{array}{ll}- & \text { Social networks } \\
& \text { Leadership } \\
- & \text { Institutions } \\
- & \text { Public perceptions } \\
& \text { of conservation } \\
- & \text { Peer pressure to } \\
\text { comply/not } \\
\text { comply } \\
\text { - } \\
\text { Trust and } \\
\text { confidence in } \\
\text { authorities } \\
\text { Willingness to } \\
\text { collaborate }\end{array}$} & $\begin{array}{ll}- & \text { Higher-level } \\
\text { policy frameworks } \\
\text { in place for } \\
\text { marine } \\
\text { management. } \\
\text { - } \quad \text { Government } \\
\text { resources and } \\
\text { effectiveness } \\
-\quad \text { Political stability } \\
\text { - } & \text { Rule of law }\end{array}$ & \\
\hline & 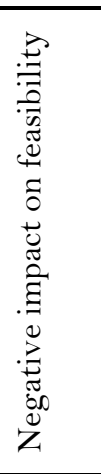 & $\begin{array}{ll}- & \text { Reduction in target } \\
\text { catch or other } \\
\text { marketable species } \\
\text { - } & \text { Operational } \\
\text { inefficiencies }\end{array}$ & $\begin{array}{ll}- & \text { Reduction in } \\
\text { food security } \\
- & \text { Reduction in } \\
& \text { livelihood } \\
\text { security } & \text { Loss of cultural } \\
- & \text { values } \\
- & \text { Reduced } \\
\text { freedom of } \\
\text { choice/agency } \\
-\quad \begin{array}{l}\text { Loss of social } \\
\text { cohesion }\end{array}\end{array}$ & $\begin{array}{ll}- & \text { Lack of skills } \\
\text { - } & \text { Limited adaptive } \\
& \text { capacity }\end{array}$ & & $\begin{array}{ll}- & \text { Conflict } \\
- & \text { Corruption }\end{array}$ & $\begin{array}{ll}- & \text { Markets } \\
- & \text { Human population } \\
- & \text { Accessibility/travel } \\
& \text { time }\end{array}$ \\
\hline \multicolumn{2}{|c|}{$\begin{array}{l}\text { Key } \\
\text { References }\end{array}$} & $\begin{array}{l}\text { Campbell \& Cornwell, } \\
\text { 2008; Dickman et al., } \\
\text { 2011; Fulton et al., 2011; } \\
\text { Gutiérrez et al., 2011; } \\
\text { Hall et al., 2007. }\end{array}$ & $\begin{array}{l}\text { Campbell \& } \\
\text { Cornwell, 2008; } \\
\text { Glaus et al., 2018; } \\
\text { Hall et al., 2007; } \\
\text { Jaiteh et al., 2016, } \\
2017 .\end{array}$ & $\begin{array}{l}\text { Hall et al., 2007; } \\
\text { Knight et al., 2010; } \\
\text { Selinske et al., 2015, } \\
2019\end{array}$ & $\begin{array}{l}\text { Barnes et al., 2016; } \\
\text { Cinner, 2018; } \\
\text { Gutiérrez et al., 2011; } \\
\text { Knight et al., 2010; } \\
\text { Oldekop et al., 2010, } \\
\text { Waylen et al., } 2010 .\end{array}$ & $\begin{array}{l}\text { Davidson \& Dulvy, } \\
\text { 2017; Dickman et al., } \\
2011 \text {. }\end{array}$ & $\begin{array}{l}\text { Dickman et al., } 2011 ; \\
\text { Davidson et al., } 2016 ; \\
\text { Cinner et al., } 2018 .\end{array}$ \\
\hline
\end{tabular}




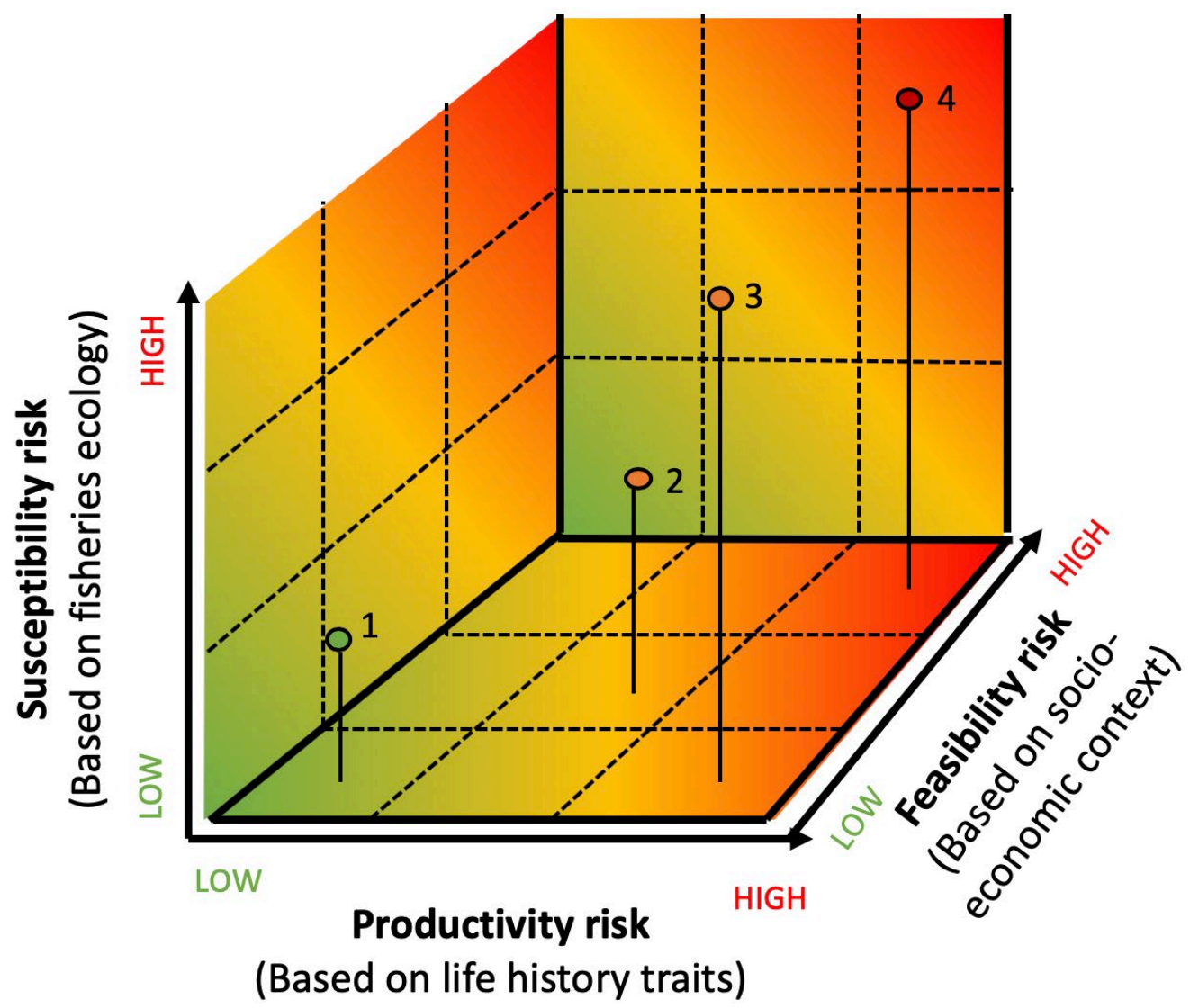

Figure 3. Schematic of a common productivity-susceptibility analysis (PSA) plot used in semi-quantitative ecological risk assessments for fisheries, with the added feasibility dimension. Point number 1 is an example of a low risk susceptibility-productivity-feasibility combination, such as the US Atlantic spiny dogfish population, while point 4 is an example of high risk across all dimensions, such as small-scale targeted fisheries for wedgefish and hammerhead sharks in Indonesia. Point 2 is moderate in all dimensions, while point 3 is high technical risk and low feasibility risk, which could represent the risks to blue sharks (2) and bigeye thresher sharks (3) caught as bycatch in high-value commercial tuna longlines.

\subsection{Understanding the human dimensions of shark fisheries}

Adopting feasibility assessments as part of shark fisheries management frameworks also requires a more in-depth understanding of the human dimensions of shark fisheries. Substantial gaps remain in our understanding of the local socio-economic factors that influence shark fishing behaviour, and how these interact with other risk factors, such as fishing technology and macro-level policy. To better manage fisheries and inform policy in the future, it would be informative to conduct detailed analyses of the drivers of shark fishing in different fishery contexts, including the relative importance of technical factors vs. social factors, and the degree to which global trade in shark- 
derived products drives local-level fishing behaviour and fishing mortality. This could be supported through socio-economic surveys (e.g. Glaus et al., 2018; Lestari et al. 2016) or psychometric methods (e.g. Selinske et al., 2015). Based on this understanding, cost-effectiveness analyses (e.g. as per Wilcox and Donlan, 2007; Gjertsen et al., 2014) and participatory predictive methods (e.g. scenario analysis, experimental games and/or choice experiments) could be used to investigate the potential effectiveness and social acceptability of a management intervention (e.g. as per Travers $e t$ al., 2011; Moro et al., 2013; Travers, Clements and Milner-Gulland, 2016). These approaches could help to provide quantitative scorings and weightings to feasibility assessments, and ultimately determine which management measures are likely to be most effective, acceptable and ethical, for both sharks and people.

\subsection{Holistic management frameworks}

Further, socio-economic factors need to be considered beyond the risk assessment phase, and systematically incorporated to prioritisation, decision-making, policy design, implementation and evaluation. The information gathered for feasibility assessments could support the setting of realistic management goals at the fishery level, which consider the constraints of the broader regulatory, cultural and economic conditions of a fishery. This can enable trade-offs between shark conservation objectives and socio-economic fisheries objectives to be made explicit when designing management measures. In turn, acknowledging trade-offs can encourage creative thinking with regard to optimal mixes of policies and instruments that can reduce costs, capitalise on heterogeneity in attitudes and motivations, and ultimately encourage wider compliance and cost-effective enforcement (Hall et al., 2007; Selinske et al., 2016). Management goals can also explicitly include socio-economic objectives and constraints, such as minimising cost or maintaining well-being of vulnerable fishers, in order to optimise outcomes for sharks and people. If quantitative targets are set as part of this process, the impacts of management on both sharks and people can be monitored and evaluated, to support learning and adaptive management. This would be a valuable contribution to shark science, particularly if proofs of concept can be provided for effective management models in small-scale fishery developing country contexts. 
750 Finally, given the magnitude of the shark conservation problem, and the nature of shared stocks and 751 pressures from multiple fisheries, it is important to ensure that the tailored solutions we advocate for here are not simply implemented though local-level, piecemeal projects. Management measures need to be adopted at scale, integrated in to national-level plans and objectives, and contribute to the achievement of international biodiversity conservation goals such as those under CITES and the Convention on Biological Diversity (CBD). This necessitates over-arching frameworks that can integrate complex, multifarious fisheries and their diverse management goals to create net positive impact - i.e. healthy shark populations - at national- and global-scales. The mitigation hierarchy, for example, has already been applied to achieving no net loss (NNL) of biodiversity in terrestrial ecosystems (Arlidge et al., 2018), and has been proposed as a step-wise precautionary approach for least-cost management of marine fisheries and bycatch mitigation (Milner-Gulland et al., 2018; Squires \& Garcia, 2018), with potential application to sharks (Milner-Gulland et al., 2018). This could provide an overarching framework to set ambitious management goals for sharks based on net impact. Thinking in net terms allows room for the fishery-specific management we advocate here, whilst ensuring aggregate impact at scale. Systematic assessment of the biological, technical and socioeconomic dimensions of fisheries within this framework could support identification of national and international priorities and approaches for meeting management goals, by identifying the most problematic fisheries in terms of fishing mortality risk, and strategic leverage points for maximising conservation impact for sharks while minimising cost to people. This holistic approach could enable identification of feasible management measures, which facilitate the recovery and maintenance of healthy shark populations, whilst ensuring the socio-economic complexities of fisheries management are no longer neglected. 
773 6. Funding sources

774 This work was supported by the Oxford NaturalMotion Graduate Scholarship. 


\section{Literature Cited}

Abrahamse, W., \& Steg, L. (2013). Social influence approaches to encourage resource conservation: A meta-analysis. Global Environmental Change, 23(6), 1773-1785. https://doi.org/10.1016/J.GLOENVCHA.2013.07.029

Ajzen, I. (1991). The theory of planned behavior. Organizational Behavior and Human Decision Processes, 5O(2), 179-211. https://doi.org/10.1016/0749-5978(91)90020-T

Allison, E. H., \& Ellis, F. (2001). The Livelihoods Approach and Management of Small-Scale Fisheries. https://doi.org/10.1016/S0308-597X(01)00023-9

Álvarez-Romero, J. G., Mills, M., Adams, V. M., Gurney, G. G., Pressey, R. L., Weeks, R., ... Storlie, C. J. (2018). Research advances and gaps in marine planning: towards a global database in systematic conservation planning. Biological Conservation, 227, 369-382. https://doi.org/10.1016/J.BIOCON.2018.06.027

Arias, A. (2015). Understanding and managing compliance in the nature conservation context. Journal of Environmental Management, 153, 134-143. https://doi.org/10.1016/J.JENVMAN.2015.02.013

Arias, A., Cinner, J. E., Jones, R. E., \& Pressey, R. L. (2015). Levels and drivers of fishers' compliance with marine protected areas. Ecology and Society, 20(4), art19. https://doi.org/10.5751/ES07999-200419

Arrizabalaga, H., de Bruyn, P., Diaz, G. A., Murua, H., Chavance, P., de Molina, A. D., ... Kell, L. T. (2011). Productivity and susceptibility analysis for species caught in Atlantic tuna fisheries. Aquatic Living Resources, 24(1), 1-12. https://doi.org/10.1051/alr/2011007

Bache, S. J. (2000). International Bycatch Policy: Options for Sea Turtle Conservation. The International Journal of Marine and Coastal Law, 15(3), 333-353. https://doi.org/10.1163/157180800X00154

Bache, S. J. (2003). Bycatch mitigation tools: selecting fisheries, setting limits, and modifying gear. Ocean and Coastal Management, 46(1-2), 103-125. Retrieved from https://www.infona.pl/resource/bwmeta 1.element.elsevier-defeoda3-ae2f-38e7-abed$6 \mathrm{~cd} 5 \mathrm{bbc} 405 \mathrm{ef}$

Ban, Natalie C., Hansen, G. J. A., Jones, M., \& Vincent, A. C. J. (2009). Systematic marine conservation planning in data-poor regions: Socioeconomic data is essential. Marine Policy, 33(5), 794-800. https://doi.org/10.1016/j.marpol.2009.02.011

Ban, Natalie Corinna, \& Klein, C. J. (2009). Spatial socioeconomic data as a cost in systematic marine conservation planning. Conservation Letters, 2(5), 206-215. https://doi.org/10.1111/j.1755263x.2009.00071.x

Barker, M. J., \& Schluessel, V. (2005). Managing global shark fisheries: suggestions for prioritizing management strategies. Aquatic Conservation: Marine and Freshwater Ecosystems, 15(4), 325-347. https://doi.org/10.1002/aqc.660

Barnes, M. L., Lynham, J., Kalberg, K., \& Leung, P. (2016). Social networks and environmental outcomes. Proceedings of the National Academy of Sciences of the United States of America, 113(23), 6466-6471. https://doi.org/10.1073/pnas.1523245113

Battista, W., Romero-Canyas, R., Smith, S. L., Fraire, J., Effron, M., Larson-Konar, D., \& Fujita, R. (2018). Behavior Change Interventions to Reduce Illegal Fishing. Frontiers in Marine Science, 5(403). https://doi.org/10.3389/fmars.2018.00403

Baum, J. K., Myers, R. A., Kehler, D. G., Worm, B., Harley, S. J., \& Doherty, P. A. (2003). Collapse and Conservation of Shark Populations in the Northwest Atlantic. Science, 299(5605), 389-392. https://doi.org/10.1126/science.1079777

Beauvais, W., Zuther, S., Villeneuve, C., Kock, R., \& Guitian, J. (2018). Rapidly assessing the risks of 
infectious diseases to wildlife species. https://doi.org/10.1098/rsos.181043

Becker, G. S. (1968). Crime and Punishment: an Economic Approach. In The Economic Dimensions of Crime (pp. 13-68). London: Palgrave Macmillan UK. https://doi.org/10.1007/978-1-34962853-7_2

Bene, C. (2006). Small-scale Fisheries: Assessing their contribution to rural livelihoods in developing countries. FAO Fisheries Circular No. 1008 (Vol. 1008). Rome. Retrieved from http://www.fao.org/3/a-j7551e.pdf

Bowles, S., \& Polanía-Reyes, S. (2019). Economic Incentives and Social Preferences: Substitutes or Complements? Part 2. Voprosy Ekonomiki, (5), 73-108. https://doi.org/10.32609/0042-87362013-5-73-108

Braccini, J. M., Gillanders, B. M., \& Walker, T. I. (2006). Hierarchical approach to the assessment of fishing effects on non-target chondrichthyans: case study of Squalus megalops in southeastern Australia. Canadian Journal of Fisheries and Aquatic Sciences, 63(11), 2456-2466. https://doi.org/10.1139/fo6-141

Braccini, M., Van Rijn, J., \& Frick, L. (2012). High Post-Capture Survival for Sharks, Rays and Chimaeras Discarded in the Main Shark Fishery of Australia? PLoS ONE, 7(2), e32547. https://doi.org/10.1371/journal.pone.0032547

Brady, M., \& Waldo, S. (2009). Fixing problems in fisheries-integrating ITQs, CBM and MPAs in management. Marine Policy, 33(2), 258-263. https://doi.org/10.1016/J.MARPOL.2008.07.002

Branstetter, S., \& Musick, J. (1993). Comparisons of Shark Catch Rates on Longlines Using Rope/Steel (Yankee) and Monofilament Gangions. Marine Fisheries Review, 55, 4-9. Retrieved from https://www.researchgate.net/publication/237475799_Comparisons_of_Shark_Catch_Rates_ on_Longlines_Using_RopeSteel_Yankee_and_Monofilament_Gangions

Brewer, D., Heales, D., Milton, D., Dell, Q., Fry, G., Venables, B., \& Jones, P. (2006). The impact of turtle excluder devices and bycatch reduction devices on diverse tropical marine communities in Australia's northern prawn trawl fishery. Fisheries Research, 81(2-3), 176-188. https://doi.org/10.1016/J.FISHRES.2006.07.009

Brewer, D., Rawlinson, N., Eayrs, S., \& Burridge, C. (1998). An assessment of Bycatch Reduction Devices in a tropical Australian prawn trawl fishery. Fisheries Research, 36(2-3), 195-215. https://doi.org/10.1016/So 165-7836(98)O0096-4

Broadhurst, M. K. (2000). Modifications to reduce bycatch in prawn trawls: A review and framework for development. Reviews in Fish Biology and Fisheries, 10(1), 27-60. https://doi.org/10.1023/A:1008936820089

Bromhead, D., Clarke, S., Hoyle, S., Muller, B., Sharples, P., \& Harley, S. (2012). Identification of factors influencing shark catch and mortality in the Marshall Islands tuna longline fishery and management implications. Journal of Fish Biology, 80(5), 1870-1894. https://doi.org/10.1111/j.1095-8649.2012.03238.x

Brooks, J. S., Waylen, K. A., \& Borgerhoff Mulder, M. (2012). How national context, project design, and local community characteristics influence success in community-based conservation projects. Proceedings of the National Academy of Sciences of the United States of America, 109(52), 21265-21270. https://doi.org/10.1073/pnas.1207141110

Bull, J. W., Baker, J., Griffiths, V. F., Jones, J. P. G., \& Milner-Gulland, E. J. (2018). Ensuring No Net Loss for people as well as biodiversity: good practice principles. SocArXiv. https://doi.org/10.31235/OSF.IO/4YGH7

Campbell, L. M., \& Cornwell, M. L. (2008). Human dimensions of bycatch reduction technology: Current assumptions and directions for future research. Endangered Species Research, 5(2-3), 325-334. https://doi.org/10.3354/esrOO172

Carr, L. A., Stier, A. C., Fietz, K., Montero, I., Gallagher, A. J., \& Bruno, J. F. (2013). Illegal shark 
fishing in the Galápagos Marine Reserve. Marine Policy, 39, 317-321.

https://doi.org/10.1016/J.MARPOL.2012.12.005

Carter, C., \& Garaway, C. (2014). Shifting Tides, Complex Lives: The Dynamics of Fishing and Tourism Livelihoods on the Kenyan Coast. Society \& Natural Resources, 27(6), 573-587. https://doi.org/10.1080/08941920.2013.842277

Challender, D. W. S., Harrop, S. R., \& MacMillan, D. C. (2015). Towards informed and multi-faceted wildlife trade interventions. Global Ecology and Conservation, 3, 129-148. https://doi.org/10.1016/J.GECCO.2014.11.010

Cinner, J. (2018). How behavioral science can help conservation. Science, 362(6417), 889-890. https://doi.org/10.1126/science.aau6028

Cinner, J., Maire, E., Huchery, C., Aaron MacNeil, M., J Graham, N. A., Mora, C., .. Mouillot, D. (2018). Gravity of human impacts mediates coral reef conservation gains. PNAS, 115(27), E6116-E6125. https://doi.org/10.1073/pnas.1708001115

Cisneros-Montemayor, A. M., Barnes-Mauthe, M., Al-Abdulrazzak, D., Navarro-Holm, E., \& Sumaila, U. R. (2013). Global economic value of shark ecotourism: Implications for conservation. Oryx, 47(3), 381-388. https://doi.org/10.1017/S0030605312001718

Clarke, S. C., McAllister, M. K., Milner-Gulland, E. J., Kirkwood, G. P., Michielsens, C. G. J., Agnew, D. J., ... Shivji, M. S. (2006). Global estimates of shark catches using trade records from commercial markets. Ecology Letters, 9(10), 1115-1126. https://doi.org/10.1111/j.14610248.2006.00968.x

Clarke, S., Milner-Gulland, E. J., \& Bjørndal, T. (2007). Social, Economic, and Regulatory Drivers of the Shark Fin Trade. Marine Resource Economics, 22(3), 305-327. https://doi.org/10.1086/mre.22.3.42629561

Cooke, S. J., \& Suski, C. D. (2004). Are circle hooks an effective tool for conserving marine and freshwater recreational catch-and-release fisheries? Aquatic Conservation: Marine and Freshwater Ecosystems, 14(3), 299-326. https://doi.org/10.1002/aqc.614

Cortés, E., Arocha, F., Beerkircher, L., Carvalho, F., Domingo, A., Heupel, M., ... Simpfendorfer, C. (2010). Ecological risk assessment of pelagic sharks caught in Atlantic pelagic longline fisheries. Aquatic Living Resources, 23(1), 25-34. https://doi.org/10.1051/alr/2009044

Courchamp, F., Angulo, E., Rivalan, P., Hall, R. J., Signoret, L., Bull, L., \& Meinard, Y. (2006). Rarity Value and Species Extinction: The Anthropogenic Allee Effect. PLoS Biology, 4(12), e415. https://doi.org/10.1371/journal.pbio.0040415

Dapp, D. R., Huveneers, C., Walker, T. I., Drew, M., \& Reina, R. D. (2016). Moving from Measuring to Predicting Bycatch Mortality: Predicting the Capture Condition of a Longline-Caught Pelagic Shark. Frontiers in Marine Science, 2, 126. https://doi.org/10.3389/fmars.2015.00126

Davidson, L. N. K. L. K., Krawchuk, M. A. M., \& Dulvy, N. K. N. N. K. (2016). Why have global shark and ray landings declined: Improved management or overfishing? Fish and Fisheries, 17(2), 438-458. https://doi.org/10.1111/faf.12119

Deci, E. L., \& Ryan, R. M. (1985). Intrinsic Motivation and Self-Determination in Human Behavior. Boston, MA: Springer US. https://doi.org/10.1007/978-1-4899-2271-7

Dent, F., \& Clarke, S. (2014). State of the Global Market for Shark Commodities (Vol. 590).

Dharmadi, Fahmi, \& Satria, F. (2015). Fisheries management and conservation of sharks in Indonesia. African Journal of Marine Science, 37(2), 249-258. https://doi.org/10.2989/1814232X.2015.1045431

Dickman, A. J. (2010). Complexities of conflict: the importance of considering social factors for effectively resolving human-wildlife conflict. Animal Conservation, 13(5), 458-466. https://doi.org/10.1111/j.1469-1795.2010.00368.x

Dulvy, N. K., Baum, J. K., Clarke, S., Compagno, L. J. V., Cortés, E., Domingo, A., ... Valenti, S. 
(2008). You can swim but you can't hide: the global status and conservation of oceanic pelagic sharks and rays. Aquatic Conservation: Marine and Freshwater Ecosystems, 18(5), 459-482. https://doi.org/10.1002/aqc.975

Dulvy, N. K., Fowler, S. L., Musick, J. A., Cavanagh, R. D., Kyne, P. M., Harrison, L. R., ... White, W. T. (2014). Extinction risk and conservation of the world's sharks and rays. ELife, 3. https://doi.org/10.7554/eLife.00590

Dulvy, N. K., Simpfendorfer, C. A., Davidson, L. N. K., Fordham, S. V, Bräutigam, A., Sant, G., \& Welch, D. J. (2017). Challenges and Priorities in Shark and Ray Conservation. Current Biology: CB, 27(11), R565-R572. https://doi.org/10.1016/j.cub.2017.04.038

Dutton, P. H., \& Squires, D. (2008). Reconciling Biodiversity with Fishing: A Holistic Strategy for Pacific Sea Turtle Recovery. Ocean Development \& International Law, 39(2), 200-222. https://doi.org/10.1080/00908320802013685

Fehr, E., \& Gächter, S. (2002). Altruistic punishment in humans. Nature, 415(6868), 137-140. https://doi.org/10.1038/415137a

Ferretti, F., Worm, B., Britten, G. G. L., Heithaus, M. R. M., \& Lotze, H. H. K. (2010). Patterns and ecosystem consequences of shark declines in the ocean. Ecology Letters, 13(8), 1055-1071. https://doi.org/10.1111/j.1461-0248.2010.01489.x

Fishbein, M. A., \& Ajzen, I. (1975). Belief, attitude, intention and behaviour: An introduction to theory and research. Reading, MA: Addison-Wesley. Retrieved from https://www.researchgate.net/publication/233897090_Belief_attitude_intention_and_behavio ur_An_introduction_to_theory_and_research

Fonseca, P., Campos, A., Larsen, R. B., Borges, T. C., \& Erzini, K. (2005). Using a modified Nordmøre grid for by-catch reduction in the Portuguese crustacean-trawl fishery. Fisheries Research, 71(2), 223-239. https://doi.org/10.1016/J.FISHRES.2004.08.018

Friedman, K., Gabriel, S., Abe, O., Adnan Nuruddin, A., Ali, A., Bidin Raja Hassan, R., ... Ye, Y. (2018). Examining the impact of CITES listing of sharks and rays in Southeast Asian fisheries. Fish and Fisheries, 19(4), 662-676. https://doi.org/10.1111/faf.12281

Fulton, E. A., Smith, A. D. M., Smith, D. C., \& Van Putten, I. E. (2011). Human behaviour: the key source of uncertainty in fisheries management. Fish and Fisheries, 12, 2-17. https://doi.org/10.1111/j.1467-2979.2010.00371.x

Gallagher, A. J., Kyne, P. M., \& Hammerschlag, N. (2012). Ecological risk assessment and its application to elasmobranch conservation and management. Journal of Fish Biology. https://doi.org/10.1111/j.1095-8649.2012.03235.x

Gallagher, A. J., Orbesen, E. S., Hammerschlag, N., \& Serafy, J. E. (2014). Vulnerability of oceanic sharks as pelagic longline bycatch. Global Ecology and Conservation, 1, 50-59. https://doi.org/10.1016/j.gecco.2014.06.003

Gallus, J. (2017). Fostering Public Good Contributions with Symbolic Awards: A Large-Scale Natural Field Experiment at Wikipedia. Management Science, 63(12), 3999-4015. https://doi.org/10.1287/mnsc.2016.2540

Gezelius, S. S. (2002). Do Norms Count? State Regulation and Compliance in a Norwegian Fishing Community: Http://Dx.Doi.Org/10.1177/000169930204500404, 45(4), 305-314. https://doi.org/10.1177/000169930204500404

Gilman, E., Boggs, C., \& Brothers, N. (2003). Performance assessment of an underwater setting chute to mitigate seabird bycatch in the Hawaii pelagic longline tuna fishery. Ocean $\&$ Coastal Management, 46, 985-1010. https://doi.org/10.1016/j.ocecoaman.2003.12.001

Gilman, E., Brothers, N., \& Kobayashi, D. R. (2005). Principles and approaches to abate seabird bycatch in longline fisheries. Fish and Fisheries, 6(1), 35-49. https://doi.org/10.1111/j.14672679.2005.00175.x 
Gilman, E., Dalzell, P., \& Martin, S. (2006). Fleet communication to abate fisheries bycatch. Marine Policy, 30(4), 360-366. https://doi.org/10.1016/J.MARPOL.2005.06.003

Gilman, E., Kobayashi, D., Swenarton, T., Brothers, N., Dalzell, P., \& Kinan-Kelly, I. (2007). Reducing sea turtle interactions in the Hawaii-based longline swordfish fishery. Biological Conservation, 139(1-2), 19-28. https://doi.org/10.1016/J.BIOCON.2007.06.002

Gjertsen, H., Squires, D., H., D. P., \& Eguchi, T. (2014). Cost-Effectiveness of Alternative Conservation Strategies with Application to the Pacific Leatherback Turtle. Conservation Biology, 28(1), 140-149. https://doi.org/10.1111/cobi.12239

Glaus, K. B. J., Adrian-Kalchhauser, I., Piovano, S., Appleyard, S. A., Brunnschweiler, J. M., \& Rico, C. (2018). Fishing for profit or food? Socio-economic drivers and fishers' attitudes towards sharks in Fiji. Marine Policy, (May), 1-9. https://doi.org/10.1016/j.marpol.2018.11.037

Gneezy, U., Meier, S., \& Rey-Biel, P. (2011). When and Why Incentives (Don't) Work to Modify Behavior. Journal of Economic Perspectives, 25(4), 191-210. https://doi.org/10.1257/jep.25.4.191

Golden, C. D., Allison, E. H., Cheung, W. W. L., Dey, M. M., Halpern, B. S., McCauley, D. J., ... Myers, S. S. (2016). Nutrition: Fall in fish catch threatens human health. Nature News, 534(7607), 317. https://doi.org/10.1038/534317a

Grafton, R. Q. (2005). Social capital and fisheries governance. Ocean E Coastal Management, 48(910), 753-766. https://doi.org/10.1016/J.OCECOAMAN.2005.08.003

Graham, F., Rynne, P., Estevanez, M., Luo, J., Ault, J. S., \& Hammerschlag, N. (2016). Use of marine protected areas and exclusive economic zones in the subtropical western North Atlantic Ocean by large highly mobile sharks. Diversity and Distributions, 22(5). https://doi.org/10.1111/ddi.12425

Graham, N. A. J., Spalding, M. D., \& Sheppard, C. R. C. (2010). Reef shark declines in remote atolls highlight the need for multi-faceted conservation action. Aquatic Conservation: Marine and Freshwater Ecosystems, 20(5), 543-548. https://doi.org/10.1002/aqc. 1116

Gutiérrez, N. L., Hilborn, R., \& Defeo, O. (2011). Leadership, social capital and incentives promote successful fisheries. Nature, 470(7334), 386-389. https://doi.org/10.1038/nature09689

Hall, M. A., Nakano, H., Clarke, S., Thomas, S., Molloy, J., Peckham, S. H., .. Hall, S. J. (2007). Working with Fishers to Reduce By-catches. In S. J. Kennelly (Ed.), By-catch Reduction in the World's Fisheries (pp. 235-288). Springer. https://doi.org/10.1007/978-1-4020-6078-6_8

Hall, R. J., Milner-Gulland, E. J., \& Courchamp, F. (2008). Endangering the endangered: The effects of perceived rarity on species exploitation. Conservation Letters, 1(2), 75-81.

https://doi.org/10.1111/j.1755-263X.2008.00013.x

Harry, A. V., Tobin, A. J., Simpfendorfer, C. A., Welch, D. J., Mapleston, A., White, J., ... Stapley, J. (2011). Evaluating catch and mitigating risk in a multispecies, tropical, inshore shark fishery within the Great Barrier Reef World Heritage Area. Marine and Freshwater Research, 62(6), 710. https://doi.org/10.1071/MF 10155

Hau, Y. C., Abercrombie, D., Ho, K. Y. K., \& Shea, K. H. S. (2018). King of Shark Fins: A rapid survey on the availability of Shark-like batoid fins in Hong Kong SAR and Guangzhou, China retail markets. Hong Kong. Retrieved from http://www.bloomassociation.org/en/wpcontent/uploads/2018/12/King-of-shark-fins-not-quite-sharks.pdf

Hilborn, R., Orensanz, J. M., \& Parma, A. M. (2005). Institutions, incentives and the future of fisheries. Trans. R. Soc. B, 360, 47-57. https://doi.org/10.1098/rstb.2004.1569

Hobday, A. J., Smith, A., Webb, H., Daley, R., Wayte, S., Bulman, C., ... Walker, T. (2007). Ecological Risk Assessment for Effects of Fishing. Retrieved from https://publications.csiro.au/rpr/download?pid=changeme:3904\&dsid=DS 1

Hossain, T., \& List, J. A. (2012). The Behavioralist Visits the Factory: Increasing Productivity 
Using Simple Framing Manipulations. Management Science, 58(12), 2151-2167.

https://doi.org/10.1287/mnsc. 1120.1544

Howey-Jordan, L. A., Brooks, E. J., Abercrombie, D. L., Jordan, L. K. B., Brooks, A., Williams, S., ... Chapman, D. D. (2013). Complex Movements, Philopatry and Expanded Depth Range of a Severely Threatened Pelagic Shark, the Oceanic Whitetip (Carcharhinus longimanus) in the Western North Atlantic. PLoS ONE, 8(2), e56588. https://doi.org/10.1371/journal.pone.0056588

Innes, J., \& Pascoe, S. (2008). Productivity Impacts of Veil Nets on UK Crangon Vessels. Journal of Agricultural Economics, 59(3), 574-588. https://doi.org/10.1111/j.1477-9552.2008.00165.x

Jaiteh, V., Lindfield, S. J., Mangubhai, S., Warren, C., Fitzpatrick, B., \& Loneragan, N. R. (2016). Higher Abundance of Marine Predators and Changes in Fishers' Behavior Following Spatial Protection within the World's Biggest Shark Fishery. Frontiers in Marine Science, 3(April), 115. https://doi.org/10.3389/fmars.2016.00043

Jaiteh, V., Loneragan, N., \& Warren, C. (2017). The end of shark finning? Impacts of declining catches and fin demand on coastal community livelihoods. Marine Policy, 82(March), 224-233. https://doi.org/10.1016/j.marpol.2017.03.027

James, K., Lewison, R. L., Dillingham, P., \& Moore, J. E. (2016). Drivers of retention and discards of elasmobranch non-target catch. Environmental Conservation, 43(1), 3-12. https://doi.org/10.1017/So376892915000168

Jenkins, L. (2006). The invention and adoption of conservation technology to successfully reduce bycatch of protected marine species. Duke University. Retrieved from https://www.researchgate.net/publication/34416953_The_invention_and_adoption_of_conse rvation_technology_to_successfully_reduce_bycatch_of_protected_marine_species

Jul-Larsen, E., Kolding, J., Overå, R., Nielsen, J. R., \& Zwieten, P. A. M. van. (2003). Management, comanagement, or no management? Major dilemmas in southern African freshwater fisheries. Rome.

Kaplan, I. C., Cox, S. P., \& Kitchell, J. F. (2007). Circle Hooks for Pacific Longliners: Not a Panacea for Marlin and Shark Bycatch, but Part of the Solution. Transactions of the American Fisheries Society, 136(2), 392-401. https://doi.org/10.1577/T05-301.1

Keane, A., Jones, J. P. G., Edwards-Jones, G., \& Milner-Gulland, E. J. (2008). The sleeping policeman: understanding issues of enforcement and compliance in conservation. Animal Conservation, 11(2), 75-82. https://doi.org/10.1111/J.14691795.2008.00170.X@10.1111/(ISSN)14691795.ANIMAL_CONSERVATION_VI_2OTH_ANNIVERSARY_COLLECTION

Knight, A. T., Cowling, R. M., Difford, M., \& Campbell, B. M. (2010). Mapping human and social dimensions of conservation opportunity for the scheduling of conservation action on private land. Conservation Biology, 24(5), 1348-1358. https://doi.org/10.1111/j.15231739.2010.01494.x

Knip, D. M., Heupel, M. R., \& Simpfendorfer, C. A. (2012). Evaluating marine protected areas for the conservation of tropical coastal sharks. Biological Conservation, 148(1), 200-209. https://doi.org/10.1016/j.biocon.2012.01.008

Kosamu, I. B. M. (2015). Conditions for sustainability of small-scale fisheries in developing countries. Fisheries Research, 161, 365-373. https://doi.org/10.1016/J.FISHRES.2014.09.002

Lack, M., \& Sant, G. (2011). The future of sharks: a review of action and inaction. TRAFFIC International and the Pew Environment Group.

Leeney, R. H., \& Poncelet, P. (2015). Using fishers' ecological knowledge to assess the status and cultural importance of sawfish in Guinea-Bissau. Aquatic Conservation: Marine and Freshwater Ecosystems, 25(3), 411-430. https://doi.org/10.1002/aqc.2419

Leeney, R., Mana, R., \& Dulvy, N. (2018). Fishers' ecological knowledge of sawfishes in the Sepik and Ramu rivers, northern Papua New Guinea. Endangered Species Research, 36, 15-26. 
https://doi.org/10.3354/esro0887

Lestari, W., Sayuti, M., Muhsin, Akbar, B., Sundari, E., \& Isnaini. (2017). [Socio economic study of shark fishers in Tanjung Luar, East Lombok, West Nusa Tenggara]. Wildlife Conservation Society-Indonesia Program.

Levi, M., Sacks, A., \& Tyler, T. (2009). Conceptualizing Legitimacy, Measuring Legitimating Beliefs. American Behavioral Scientist, 53(3), 354-375. https://doi.org/10.1177/0002764209338797

Mace, G. M., Collar, N. J., Gaston, K. J., Hilton-Taylor, C., Akçakaya, H. R., Leader-Williams, N., ... Stuart, S. N. (2008). Quantification of extinction risk: IUCN's system for classifying threatened species. Conservation Biology, 22(6), 1424-1442. https://doi.org/10.1111/j.15231739.2008.01044.x

MacKeracher, T., Diedrich, A., \& Simpfendorfer, C. A. (2018). Sharks, rays and marine protected areas: A critical evaluation of current perspectives. Fish and Fisheries. https://doi.org/10.1111/faf.12337

Manire, C., Hueter, R., Hull, E., \& Spieler, R. (2001). Serological Changes Associated with Gill-Net Capture and Restraint in Three Species of Sharks. Transactions of the American Fisheries Society, 130(6), 1038-1048. https://doi.org/10.1577/1548-8659(2001)130<1038:SCAWGN>2.0.CO;2

Margavio, A. V., \& Forsyth, C. J. (1996). Caught in the net: the conflict between shrimpers and conservationists. In Pratt JA (Ed.), Kenneth E. Montague series in oil and business history (7th ed.). Texas: Texas A\&M University Press. Retrieved from http://agris.fao.org/agrissearch/search.do?recordID=US19960119059

Matias Braccini, J., \& Waltrick, D. (2019). Species-specific at-vessel mortality of sharks and rays captured by demersal longlines. Marine Policy, 99(February 2018), 94-98. https://doi.org/10.1016/j.marpol.2018.10.033

Maxwell, S. M., Hazen, E. L., Lewison, R. L., Dunn, D. C., Bailey, H., Bograd, S. J., ... Crowder, L. B. (2015). Dynamic ocean management: Defining and conceptualizing real-time management of the ocean. Marine Policy, 58, 42-50. https://doi.org/10.1016/J.MARPOL.2015.03.014

Mbaru, E. K., \& Barnes, M. L. (2017). Key players in conservation diffusion: Using social network analysis to identify critical injection points. Biological Conservation, 210, 222-232. https://doi.org/10.1016/J.BIOCON.2017.03.031

McClanahan, T. R., Marnane, M. J., Cinner, J. E., \& Kiene, W. E. (2006). A Comparison of Marine Protected Areas and Alternative Approaches to Coral-Reef Management. Current Biology, 16(14), 1408-1413. https://doi.org/10.1016/J.CUB.2006.05.062

McClenachan, L., Cooper, A. B., \& Dulvy, N. K. (2016). Rethinking Trade-Driven Extinction Risk in Marine and Terrestrial Megafauna. Current Biology: CB, 26(12), 1640-1646. https://doi.org/10.1016/j.cub.2016.05.026

Milner-Gulland, E. J., Garcia, S., Arlidge, W., Bull, J., Charles, A., Dagorn, L., ... Squires, D. (2018). Translating the terrestrial mitigation hierarchy to marine megafauna by-catch. Fish and Fisheries, 19(3), 547-561. https://doi.org/10.1111/faf.12273

Milner-Gulland, E. J., Mcgregor, J. A., Agarwala, M., Atkinson, G., Bevan, P., Clements, T., ... Wilkie, D. (2014). Accounting for the impact of conservation on human well-being. Conservation Biology, 28(5), 1160-1 166. https://doi.org/10.1111/cobi.12277

Momigliano, P., \& Harcourt, R. (2014). Shark conservation, governance and management: The science-law disconnect. In N. Klein \& E. Techera (Eds.), Sharks: conservation, governance and management (pp. 89-106). Abingdon, UK: Earthscan Series. https://doi.org/10.4324/9780203750292

Moro, M., Fischer, A., Czajkowski, M., Brennan, D., Lowassa, A., Naiman, L. C., \& Hanley, N. (2013). An investigation using the choice experiment method into options for reducing illegal bushmeat hunting in western Serengeti. Conservation Letters, 6(1), 37-45. 
https://doi.org/10.1111/j.1755-263X.2012.00284.X

Musick, J., Burgess, G., Cailliet, G., Camhi, M., \& Fordham, S. (2000). Management of Sharks and Their Relatives (Elasmobranchii). Fisheries, 9-13. Retrieved from http://www.adfg.alaska.gov/staticsf/Region2/ground_fish/PDFs/AFSMarineStocksAtRisk31b_sharks.pdf

O’Keefe, C. E., Cadrin, S. X., \& Stokesbury, K. D. E. (2014). Evaluating effectiveness of time/area closures, quotas/caps, and fleet communications to reduce fisheries bycatch. ICES Journal of Marine Science, 71(5), 1286-1297. https://doi.org/10.1093/icesjms/fsto63

O’Malley, M. P., Lee-Brooks, K., \& Medd, H. B. (2013). The Global Economic Impact of Manta Ray Watching Tourism. PLoS ONE, 8(5). https://doi.org/10.1371/journal.pone.0065051

Oldekop, J. A., Bebbington, A. J., Brockington, D., \& Preziosi, R. F. (2010). Entendiendo las lecciones y limitaciones de la conservación y el desarrollo. Conservation Biology, 24(2), 461-469. https://doi.org/10.1111/j.1523-1739.2010.01456.x

Oliver, S., Braccini, M., Newman, S. J., \& Harvey, E. S. (2015). Global patterns in the bycatch of sharks and rays. Marine Policy, 54, 86-97. https://doi.org/10.1016/j.marpol.2014.12.017

Patterson, H., Hansen, S., \& Larcombe, J. (2014). A review of shark bycatch mitigation in tuna longline fisheries. In WCPFC Scientific Committee tenth regular session. Majuro, Republic of the Marshall Islands.

Pentland, A. (2014). Social Physics: How good ideas spread-the lessons from a new science. Penguin Press.

Poisson, F., Gaertner, J. C., Taquet, M., Durbec, J. P., \& Bigelow, K. (2010). Effects of lunar cycle and fishing operations on longline-caught pelagic fish: Fishing performance, capture time, and survival of fish. Fishery Bulletin(Vol. 108). Retrieved from http://aquaticcommons.org/8745/1/9019.pdf

Polasky, S. (2008). Why conservation planning needs socioeconomic data. Proceedings of the National Academy of Sciences of the United States of America, 105(18), 6505-6506. https://doi.org/10.1073/pnas.0802815105

Rausser, G., Hamilton, S., Kovach, M., \& Stifter, R. (2009). Unintended consequences: The spillover effects of common property regulations. Marine Policy, 33(1), 24-39. https://doi.org/10.1016/J.MARPOL.2008.03.020

Redpath, S. M., Young, J., Evely, A., Adams, W. M., Sutherland, W. J., Whitehouse, A., ... Gutiérrez, R. J. (2013). Understanding and managing conservation conflicts. Trends in Ecology and Evolution, 28(2), 100-109. https://doi.org/10.1016/j.tree.2012.08.021

Rigby, C., Appleyard, S., Chin, A., Heupel, M., Humber, F., Jeffers, V., ... Campbell, I. (2019). Rapid Assessment Toolkit for Sharks and Rays. Retrieved from https://sharks.panda.org/images/RAT/pdf/WWF_RapidAssessmentToolkitSharksRays_201 9_V10.pdf

Ryan, R. M., \& Deci, E. L. (2002). Overview of self-determination theory: An organismic-dialectical perspective. In E. L. Deci \& R. M. Ryan (Ed.), Handbook of self-determination research (pp. 3-33). Rochester, NY, US: University of Rochester Press. Retrieved from https://psycnet.apa.org/record/2002-01702-001

Sarmiento, C. (2006). Transfer function estimation of trade leakages generated by court rulings in the Hawai'i longline fishery. Applied Economics, 38(2), 183-190. https://doi.org/10.1080/00036840500368078

Selinske, M. J., Coetzee, J., Purnell, K., \& Knight, A. T. (2015). Understanding the Motivations, Satisfaction, and Retention of Landowners in Private Land Conservation Programs. Conservation Letters, 8(4), 282-289. https://doi.org/10.1111/conl.12154

Selinske, M. J., Cooke, B., Torabi, N., Hardy, M. J., Knight, A. T., \& Bekessy, S. A. (2017). Locating financial incentives among diverse motivations for long-term private land conservation. Ecology and Society, 22(2), art7. https://doi.org/10.5751/ES-09148-220207 
Selinske, M. J., Howard, N., Fitzsimons, J. A., Hardy, M. J., Smillie, K., Forbes, J., ... Knight, A. T. (2019). Monitoring and evaluating the social and psychological dimensions that contribute to privately protected area program effectiveness. Biological Conservation, 229, 170-178. https://doi.org/10.1016/J.BIOCON.2018.11.026

Serafy, J. E., Orbesen, E. S., Snodgrass, D. J., Beerkircher, L. R., \& Walter, J. F. (2012). Hooking Survival of Fishes Captured by the United States Atlantic Pelagic Longline Fishery: Impact of the 2004 Circle Hook Rule. Bulletin of Marine Science, 88(3), 605-621. https://doi.org/10.5343/bms.2011.1080

Shiffman, D., \& Hammerschlag, N. (2016). Shark conservation and management policy: a review and primer for non-specialists. Animal Conservation, 19(5), 401-412. https://doi.org/10.1111/acv.12265

Simpfendorfer, C., \& Dulvy, N. K. (2017). Bright spots of sustainable shark fishing. Current Biology, 27(3), R97-R98. https://doi.org/10.1016/j.cub.2016.12.017

Simpfendorfer, C., Heupel, M., White, W. T., \& Dulvy, N. K. (2011). The importance of research and public opinion to conservation management of sharks and rays: A synthesis. Marine and Freshwater Research, 62(6), 518-527. https://doi.org/10.1071/MF 11086

Squires, D., \& Garcia, S. (2018). The least-cost biodiversity impact mitigation hierarchy with a focus on marine fisheries and bycatch issues. Conservation Biology, 32(5), 989-997. https://doi.org/10.1111/cobi.13155

Stein, R. W., Mull, C. G., Kuhn, T. S., Aschliman, N. C., Davidson, L. N. K., Joy, J. B., ... Mooers, A. O. (2018). Global priorities for conserving the evolutionary history of sharks, rays and chimaeras. Nature Ecology and Evolution. https://doi.org/10.1038/s41559-017-0448-4

Stern, M. J. (2018). Social science theory for environmental sustainability: a practical guide. Oxford University Press.

Stevens, J., Bonfil, R., Dulvy, N. K., \& Walker, P. A. P. (2000). The effects of fishing on sharks, rays, and chimaeras (chondrichthyans), and the implications for marine ecosystems. ICES Journal of Marine Science, 57(3), 476-494. https://doi.org/10.1006/jmsc.2000.0724

Thaler, R. H. (2018). From Cashews to Nudges: The Evolution of Behavioral Economics. American Economic Review, 108(6), 1265-1287. https://doi.org/10.1257/aer.108.6.1265

Thirgood, S., \& Redpath, S. (2008). Hen harriers and red grouse: science, politics and human-wildlife conflict. Journal of Applied Ecology, 45(5), 1550-1554. https://doi.org/10.1111/j.13652664.2008.01519.x

Thorpe, T., \& Frierson, D. (2009). Bycatch mitigation assessment for sharks caught in coastal anchored gillnets. Fisheries Research, 98(1-3), 102-112. https://doi.org/10.1016/J.FISHRES.2009.04.003

Tolotti, M. T., Filmalter, J. D., Bach, P., Travassos, P., Seret, B., \& Dagorn, L. (2015). Banning is not enough: The complexities of oceanic shark management by tuna regional fisheries management organizations. Global Ecology and Conservation, 4, 1-7. https://doi.org/10.1016/J.GECCO.2015.05.003

Travers, H., Clements, T., Keane, A., \& Milner-Gulland, E. J. (2011). Incentives for cooperation: The effects of institutional controls on common pool resource extraction in Cambodia. Ecological Economics, 71, 151-161. https://doi.org/10.1016/J.ECOLECON.2011.08.020

Travers, H., Clements, T., \& Milner-Gulland, E. J. (2016). Predicting responses to conservation interventions through scenarios: A Cambodian case study. Biological Conservation, 204, 403410. https://doi.org/10.1016/j.biocon.2016.10.040

Tyler, T. R. (1990). Why People Obey the Law - Tom R. Tyler - Google Books. New Haven: Yale University Press. Retrieved from https://books.google.co.id/books?hl=en\&lr=\&id=0uk9DwAAQBAJ\&oi=fnd\&pg=PP7\&ots=Y T-jvI_SJs\&sig=XteORp_VLi-q5EcvLJ1YgLJovQo\&redir_esc=y\#v=onepage\&q\&f=false 
Ward-Paige, C. A., Keith, D. M., \& Lotze, H. K. (2012). Recovery potential and conservation options for elasmobranchs. Journal of Fish Biology, 80, 1844-1869. https://doi.org/10.1111/j.10958649.2012.03246.x

Ward-Paige, C., \& Worm, B. (2017). Global evaluation of shark sanctuaries. Global Environmental Change, 47, 174-189. https://doi.org/10.1016/J.GLOENVCHA.2017.09.005

Ward, P., Lawrence, E., Darbyshire, R., \& Hindmarsh, S. (2008). Large-scale experiment shows that nylon leaders reduce shark bycatch and benefit pelagic longline fishers. Fisheries Research, 90(13), 100-108. https://doi.org/10.1016/j.fishres.2007.09.034

Waylen, K. A., Fischer, A., Mcgowan, P. J. K., Thirgood, S. J., \& Milner-Gulland, E. J. (2010). Effect of local cultural context on the success of community-based conservation interventions. Conservation Biology, 24(4), 1119-1 129. https://doi.org/10.1111/j.1523-1739.2010.01446.x

Weimerskirch, H., Catard, A., Prince, P. A., Cherel, Y., \& Croxall, J. P. (1999). Foraging whitechinned petrels Procellaria aequinoctialis at risk: from the tropics to Antarctica. Biological Conservation, 87(2), 273-275. https://doi.org/10.1016/So006-3207(98)00039-1

White, E. R., Myers, M. C., Flemming, J. M., \& Baum, J. K. (2015). Shifting elasmobranch community assemblage at Cocos Island-an isolated marine protected area. Conservation Biology, 29(4), 1186-1197. https://doi.org/10.1111/cobi.12478

White, W. T., \& Last, P. R. (2012). A review of the taxonomy of chondrichthyan fishes: a modern perspective. Journal of Fish Biology, 80, 901-917. https://doi.org/10.1111/j.10958649.2011.03192.x

Wilcox, C., \& Donlan, C. J. (2007). Compensatory mitigation as a solution to fisheries bycatchbiodiversity conservation conflicts. Frontiers in Ecology and the Environment, 5(6), 325-331. https://doi.org/10.1890/1540-9295(2007)5[325:CMAAST]2.0.CO;2

Woodhouse, E., Homewood, K. M., Beauchamp, E., Clements, T., McCabe, J. T., Wilkie, D., \& Milner-Gulland, E. J. (2015). Guiding principles for evaluating the impacts of conservation interventions on human well-being. Philosophical Transactions of the Royal Society B: Biological Sciences, 370(1681), 20150103. https://doi.org/10.1098/rstb.2015.0103

Worm, B., Davis, B., Kettemer, L., Ward-Paige, C. A., Chapman, D., Heithaus, M. R., ... Gruber, S. H. (2013). Global catches, exploitation rates, and rebuilding options for sharks. Marine Policy, 40, 194-204. https://doi.org/10.1016/j.marpol.2012.12.034

Yates, P. M., Tobin, A. J., Heupel, M. R., \& Simpfendorfer, C. A. (2016). Benefits of marine protected areas for tropical coastal sharks. Aquatic Conservation: Marine and Freshwater Ecosystems, 26(6), 1063-1080. https://doi.org/10.1002/aqc.2616

Yulianto, I., Booth, H., Ningtias, P., Kartawijaya, T., Santos, J., Sarmintohadi, ... Hammer, C. (2018). Practical measures for sustainable shark fisheries: Lessons learned from an Indonesian targeted shark fishery. PLOS ONE, 13(11), e0206437. https://doi.org/10.1371/journal.pone.0206437

Zhang, X., \& Vincent, A. C. J. (2019). Conservation prioritization for seahorses (Hippocampus spp.) at broad spatial scales considering socioeconomic costs. Biological Conservation, 235, 79-88. https://doi.org/10.1016/J.BIOCON.2019.04.008 